Volume 1

Issue 1 Transformative Possibilities:

Transcending Interlocking Boundaries

\title{
Constructs of Freedom and Identity: The Ethnogenesis of the Jamaican Maroons and the Treaties of 1739
}

Jessica Krug

Portland State University

Follow this and additional works at: https://pdxscholar.library.pdx.edu/mcnair Let us know how access to this document benefits you.

\section{Recommended Citation}

Krug, Jessica (2004) "Constructs of Freedom and Identity: The Ethnogenesis of the Jamaican Maroons and the Treaties of 1739," PSU McNair Scholars Online Journal: Vol. 1: Iss. 1, Article 6.

https://doi.org/10.15760/mcnair.2005.213

This open access Article is distributed under the terms of the Creative Commons Attribution-NonCommercialShareAlike 4.0 International License (CC BY-NC-SA 4.0). All documents in PDXScholar should meet accessibility standards. If we can make this document more accessible to you, contact our team. 
Portland State University McNair Research Journal 2004-2005

Constructs of Freedom and Identity: The Ethnogenesis of the Jamaican Maroons and the Treaties of 1739

by

Jessica Krug

Faculty Mentor:

John Ott

Citation: Krug, Jessica. Constructs of Freedom and Identity: The Ethnogenesis of the Jamaican Maroons and the Treaties of 1739. Portland State University McNair Scholars Online Journal, Vol. 1, 2004-2005: 213-277. 


\title{
Constructs of Freedom and Identity: The Ethnogenesis of the Jamaican Maroons and the Treaties of 1739
}

\author{
Jessica Krug \\ Faculty Mentors: John Ott
}

\section{INTRODUCTION}

Conceptions of justice and normalcy are both culturally specific and time-bound, but many people, across cultures and throughout time, believe that their standard of justice is universal and objective. Modern Americans writhe in anger and horror discussing the situation of women in the Middle East; indigenous Americans in the fifteenth century were appalled by the European's infrequent bathing and other unhygienic habits. Few issues in the world history, though, provoke the same type of revulsion, judgment, and revisionism as slavery. Slavery, understandably, is a topic connected to great passion and deep-seeded, though often poorly understood, feelings for many modern people. In the New World, people are less than two centuries removed from the experience of slavery; in Africa, where abolition occurred much later, the memories are often only three or four generations distant. In the New World, those who are descended from those formerly enslaved continue to suffer discrimination, prejudice, and the economic deprivations that are the legacy of slavery. Furthermore, the racist institutions that permeate Western culture have failed to provide a sense of history and cultural significance to the descendents of enslaved people. The descendents of the slaveholders, conversely, are conditioned to discuss slavery as a historical phenomenon that, while regrettable, has no ramifications for the modern world.

Of course, slavery continues to shape global societies. As many have argued, capitalism, as it exists today, would not have been possible without slave-centered production. The slave trade has greatly influenced social realities for much of the New World and Africa. In Africa, the slave trade removed millions of productive people from their communities and families, and many millions of others were displaced or killed. In the New World, slaves not only contributed the labor power upon which many societies were founded, but also fashioned new, syncretic cultures that have become, in America and the Caribbean, national cultures. Throughout the New World, the descendents of the enslaved often express hostility and outrage towards Africans and African immigrants, whom they accuse of betraying them.

The rhetoric of perfidy permeates not only African/New World relations, but also relations between two markedly different groups. Within the slave societies of the New World, and in Africa, 
people reacted against the condition of enslavement and against the slave trade. The people who reacted against the condition of enslavement and formed autonomous communities wherein the society and culture were organized in terms different from that of the hegemonic society are known as Maroons. Because the Maroons did not rebel against the institutions of racialized slavery generally, but rather worked to secure their own freedom, they are often depicted as traitors by the descendents of enslaved people, or even descendents of slaveholders who are mired in feelings of guilt. Maroons fought not for the end of racialized slavery, or change of any sort within the dominant society, but rather for the agency to create their own society.

The Oxford English Dictionary attributes the earliest use of the term Maroon to Sir Francis Drake, who, in 1626, wrote of "[t]he Symerons (a blacke people, which about eightie yeeres past, fled from the Spaniards their Masters)."1 This usage supports the assertion of Price and others that the etymology of Maroon is related to the Spanish word cimarron, meaning feral cattle. ${ }^{2}$ One possible reason for this word evolution is the employment of slaves in hunting wild cattle in the period of Spanish occupation of Jamaica, prior to 1655. More likely, however, the derivation of Maroon from cimarron connotes the manner in which the European culture constructed African identity. In many respects, the history of the word "Maroon" is similar in function to the history of the application of the term "chattel" to slaves: both served effectively to dehumanize human beings, thus rendering less cognitively dissonant the practice of human slavery for individual liberty-professing slaveholders. $^{3}$

However the slaveholders endeavored to dehumanize the enslaved, the enslaved were not tabula rasa labor units, but had their own culturally constructed notions of community and freedom. In eighteenth-century Jamaica, the disparity between three worldviews, that of the slaveholder, that of the Maroons, and that of the enslaved who remained on the plantations, came into conflict. The British fought against the rebel slaves who lived in the inaccessible interior of the island from the time the British conquered the island from the Spanish in 1655 until they signed peace treaties with the Maroons in 1739. The weapons in these battles were not only military, but also spiritual and psychological. After the signing of the peace treaties and the formal recognition of the Maroon communities as autonomous polities, the Maroons and the still-enslaved conflicted over their differing perceptions of freedom. The still-enslaved continued to flee and rebel, but, increasingly,

\footnotetext{
${ }^{1}$ Oxford English Dictionary, $2^{\text {nd }}$ ed., s.v. "Maroon."

${ }^{2}$ Mavis C. Campbell, The Maroons of Jamaica 1655-1796: A History of Resistance, Collaboration, and Betrayal (Massachusetts: Bergin \& Garvey Publishers, Inc., 1988), 1.

${ }^{3}$ Oxford English Dictionary, $2^{\text {nd }}$ ed., s.v. "chattel."
} 
they sought equity within the hegemonic society; the Maroons never wanted inclusion in the dominant society, but rather freedom from it.

It is from this conflict that the still-prevailing belief that the Maroons are traitors derives. The Maroons shifted from rebel slaves to rebel slave hunters and killers; even after Emancipation, the Maroons aided the British in quashing uprisings and protests. While Britain and its colonies remained a largely feudal society, the notion of socially reciprocal obligations between members of different classes and polities closely matched African views, held by the Maroons, about social duties. Once the British and the still-enslaved adopted a notion of individual rights, however, perceptions of the Maroons changed.

It is within this highly charged climate that any discussion of Maroon ethnogenesis must occur. Sources available today are informed by these widely divergent conceptions of justice and notions of violation of that justice. Some of these perceptions originate from the historical actors, while some originate in twentieth-century and twenty-first-century conceptions like racial consciousness, Pan-Africanism, and Rastafarianism. People, it must be recognized, do not believe or act the same across time and place. Eighteenth-century Jamaican Maroons are not the contemporaries of Marcus Garvey or Bob Marley. The problems they confronted are not the same problems faced by Jamaicans today.

But a comprehension of the problems faced by those who formed the Maroon communities in eighteenth-century Jamaica is crucial to an understanding of the historical basis for modern Jamaican, and those seeking to create national identities in newly-independent nations like Jamaica could learn much from a study of the ethnogenesis of the Jamaican Maroons. Those who left the slavery system to form their own communities faced not only the difficulties of surviving while being pursued by the British military, but also the predicament of forging functional and cohesive communities from diverse, and often not amenable, constituents. Within the brief span of one or two generations, rebellious Asante, Fante, Ga, Igbo, Congo, and Madagascan transformed into the Jamaican Maroons. This process was not largely one of top-down ordinance, but rather of mythmaking and symbolic rituals of inclusion. Further, the construction of a Maroon ethnicity was also predicated upon the exclusion of non-Maroon, both in the form of catching of rebel slaves and repression of slave rebellion, and in the ownership by the Maroons of slaves. The Maroons did not end the institution of slavery, but they ended the condition of their own enslavement, and so made possible such actions as the successful revolt in Haiti, which, ultimately, collapsed racialized slavery in the New World. Understanding the ethnogenesis of the Jamaican Maroons provides an excellent 
opportunity for people to escape the narrow duality of victim-and-oppressor which most often shapes discussion of the history of slavery.

\section{REVIEW OF LITERATURE}

Though the benefits of post-modern thought to the practice of history are putative and highly contentious, the dismantling of the wie es eigentlich gewesen pretension of modernist historians has undoubtedly benefited the study of histories of non-European peoples. However, many historians still find difficulty in expressly detailing the biases within their work. Historians of the Maroons are no exception. Deconstructionists may argue that the explicit or implicit agendas of historians belabor all history; Maroon history, however, has been particularly plagued by anachronistic and culturally inappropriate perspectives. From the earliest written accounts of the Jamaican Maroons, such as Edward Long's three volume The History of Jamaica (1774) and Robert Charles Dallas's The History of the Maroons (1803), to more recent works like Werner Zips' Black Rebels (1999), predominantly Euro-American and European scholars have placed their own social burdens upon the backs of the Jamaican Maroons.

The earliest writers distorted the Maroons to serve the varied needs of the British Empire. During the eighteenth century, the British Empire engaged in a multitude of struggles against Spain, France, and Portugal. Because Britain took Jamaica from the Spanish in 1655, the threat of Spanish re-conquest was always foremost in the minds of British officials and writers. Thus, Dallas attributes late seventeenth-century Maroon hostility towards British planters to "[the Maroons being] instigated by their former masters to commit hostilities against the new possessors of the country; a supposition by no means improbable, as the Spaniards...might purposely have kept up a communication." $^{4}$ This view of Maroons as pawns of the interest of Empire was certainly not restricted to historians; many of the discussions recorded in The Journals of the Assembly of Jamaica reflect a concern on the part of the British that either the French or the Spanish would forge an alliance with the Maroons and drive the British from their profitable sugar colony. ${ }^{5}$

Competition against other empires, however, was not the sole need of the British Empire served by historians. By the end of the eighteenth century, abolitionist sentiment abounded in Great Britain. The London Committee, a prominent and vociferous group of influential citizens intent on

\footnotetext{
${ }^{4}$ Robert Charles Dallas, The History of the Maroons: From Their Origin to the Establishment of Their Chief Tribe at Sierra Leone, vol. 1 (London: Frank Cass and Company, 1803; reprint, 1968), 24-5.

${ }^{5}$ Journals of the Assembly of Jamaica.
} 
abolition formed by 1787, and William Wilberforce "had already made known his intention of introducing the subject of the slave trade in the house of commons [sic]." As abolitionists gained popular support even prior to the organization of this influential group, historians had an added impetus to animalize the Maroons and normalize slavery. Edward Long, one of the earliest historians of Jamaica, argued that the British traffic in slaves prevented the enslaved from suffering "those horrid methods of diminishing them [in Africa], of which we read in history, by sacrificing them to their fetishes and great men; butchering their captives in war, and, in most of the provinces, devouring human flesh."7 Long was clearly responding to abolitionist critiques when he wrote, "a Briton therefore, who has always lived in fruition of a rational freedom, must not judge of every other man's feelings by his own; because they who have never experienced the same British freedom, or any degree near to it, cannot possibly hold the same opinion of slavery that a Briton does." As the eighteenth century ended, racial schemata rigidified, and racialized rationalizations like Long's became commonplace.

With slavery thus described as natural for Africans and vastly preferable to the violence and depravity ostensibly suffered in Africa, maroonage, to Long, represented an abhorrent, unnatural break in the Great Chain of Being. To Long, the only possible explanation for maroonage was the Maroon's desire "to rescue themselves from a life of Labour by force of arms." The purpose of such an account could only be to assuage mounting pangs of conscience on the part of British citizens. Though the rhetorical devices employed by Long and Dallas seem preposterous to modern readers, later historians of Maroons have often erred in a similar way.

Historians have seldom allowed the Maroons represent only themselves. To Long and Dallas, they were dangerous enemies of empire and subverters of the right and natural order of the world. To later writers, the Maroons represent a failed possibility of full-scale rebellion against plantation slavery and capitalism. The standard and oft-quoted recent work of Jamaican Maroon history, Mavis C. Campbell's The Maroons of Jamaica, 1655-1796: A History of Resistance, Collaboration and Betrayal, commits this fallacy. The very title of the work suggests that the Maroons abandoned a struggle, but nowhere in the work does Campbell explore what that struggle meant to the Maroons. Indeed, Campbell's work has been criticized as beset by a "lack of clarity [resulting from] a narrow

\footnotetext{
${ }^{6}$ J.R. Oldfield, “The London Committee and Mobilization of Public Opinion Against the Slave Trade," The Historical Journal 35 (1992): 332.

${ }^{7}$ Long, 387.

${ }^{8}$ Long, 401 .

${ }^{9}$ Long, 445 .
} 
understanding of what freedom meant to maroons [sic] in the Jamaican context, as well as from an idealistic, if not romantic, notion of the politics of antislavery."10 The legacy of slavery is not easy to contemplate, particularly for those who continue to benefit from its exercise at the expense of those descended from the enslaved; criticizing the Maroons for not having demolished a system so clearly objectionable to twenty-first century thinkers is both poor history craft and alarming in its lack of critical approach to history, race, and slavery.

Werner Zips compounds the same errors of anachronism with a conflation of Maroon society and Rastafarian culture in Black Rebels: African Caribbean Freedom Fighters in Jamaica, which he promises to write as "a 'history of resistance' rather than a 'history of domination'."11 This Manichean perception of Maroon history is grounded in the world of the author rather than that of the Maroons, for syncretism and negotiation are defining characteristics of Maroon history. The author states that he "first developed an interest in Jamaica and the Caribbean by listening to the reggae texts of Bob Marley and Burning Spear in the 1970s...Rastafari contextualized and thereby historicized my original understanding."12 Rastafarian culture has certainly made significant inroads into contemporary Maroons communities, particularly in Accompong (where one of the few maker of the traditional Maroon drums, George Huggins, is an outspoken Rastafarian), but eighteenthcentury Maroons were not Rastafarians. Perhaps even more phenomenal than the Maroon military victory over the British was the Maroon forging of a new ethnic consciousness; this new consciousness, however, was never of a Pan-African nature. Throughout his writing, Zips interprets events in Maroon history through a lens of heroic resistance, more appropriate to $1970 \mathrm{~s}$ revolutionary music than the Blue Mountains and Cockpits of eighteenth-century Jamaica.

Similar issues of ahistorical revisionism afflict the discourse surrounding the issue of Maroons keeping slaves. Contemporary Maroons vehemently deny that the Maroons ever had slaves. Victor Reid, official abeng blower for the Accompong Maroons, asserts "Nanny did not have no slave out here," and, furthermore, Maroons were freedom fighters struggling against the institution of slavery. British lies are the basis for any assertion that the Maroons had slaves, according to Reid. ${ }^{13}$ Colonel Sydney Peddie, leader of the Accompong Maroons, and Colonel

\footnotetext{
${ }^{10}$ Hilary Beckles, review of The Maroons of Jamaica, 1655-1796: A History of Resistance, Collaboration and Betrayal, by Mavis C. Campbell, The Journal of American History 76 (1989): 579.

${ }^{11}$ Werner Zips, Black Rebels: African Caribbean Freedom Fighters in Jamaica (Princeton, N.J.: Markus Wiener Publishers, 1999), xi.

${ }^{12}$ Zips, 3.

${ }^{13}$ Victor Reid, interview by author, Accompong, Jamaica, 6 August 2004.
} 
Wallace Sterling, leader of the Moore Town Maroons, echo these denials. ${ }^{14}$ Of course, secrecy has long been a salient feature of Maroon societies. To even modern Maroons, discussing such a controversial topic may seem fraught with danger. Furthermore, Maroons are not culturally isolated, and continuing contact with the wider Jamaican population, and the obvious infusion of Rastafarian and Pan-African ideas into Maroon communities, could greatly influence Maroon interpretation and valancing of elements of Maroon history, as it obviously has shaded the views of non-Maroon historians.

Perhaps more disquieting to the historian is the high probability of a phenomenon known as feedback in Maroon oral histories, operating to alter Maroon historical memory to adhere to modern Jamaican values. Feedback "occurs in oral tradition when extraneous material, usually from printed sources, is incorporated into the tradition."15 The Jamaican Maroons are certainly aware of the extent to which outside historians, anthropologists, linguists, ethnomusicologists, and others have studied their culture. Modern Maroons often reference the work of scholars in interviews, sometimes deliberately and sometimes unconsciously. Commenting on the dangers of such a process in his study of oral tradition amongst the Saramaka Maroons of Suriname, Richard Price comments: "I am struck forcefully and painfully...by the ways in which my authority influences or crystallizes or freezes 'the truth' for those Saramakas who hear it." "16 In a similar fashion, the anachronistic perspective of non-Maroon scholars who project a kind of pan-African, Marxist revolutionary, racialized consciousness onto the eighteenth-century Maroon may have indelibly influenced the Maroons' memory of their own history. With the prestige of the written word, a powerful by-product of colonialism, in addition to incredible social and political pressures, the Maroons may be adhering, on some level, to the simulacrum of maroonage created by outsiders.

Some more recent scholarship self-consciously seeks to avoid contributing to this simulacrum by incorporating the work of Maroon scholars and leaders with that of outside scholars, many of whom are trained Africanists. The essays collected in Maroon Heritage, assembled from a conference on Maroon Heritage at the University of the West Indies, Mona, in October 1991, are examples of this kind of approach. Though the authors whose work is represented in this collection come from a variety of academic disciplines and backgrounds, they often utilize the methodology of

\footnotetext{
${ }^{14}$ Colonel Sydney Peddie, interview by author, Accompong, Jamaica, 7 August 2004. Colonel Wallace Sterling, interview by author, Moore Town, Jamaica, 9 August 2004.

${ }^{15}$ David P. Henige, "The Problem of Feedback in Oral Tradition: Four Examples From the Fante Coastland," The Journal of African History 14 (1973): 223.

${ }^{16}$ Richard Price, First Time: The Historical Vision of an Afro-American People (Baltimore: The Johns Hopkins University Press, 1983): 23.
} 
the cultural anthropologist; many of the authors seeks to explain various elements of Maroon culture in terms of adaptive responses to particular historical and environmental traditions, or else use an understanding of African languages and cultural practices to contextualize Maroon societies without essentializing them. ${ }^{17}$ While this approach represents an encouraging development in the study of the Maroons, the authors in the volume also fail to address some of the more controversial elements of Maroon history. For example, the essay "Maroons and Rebels (a Dilemma)," which comes closest to discussing contentious issues, dismisses the deep resentment and mistrust with which modern Jamaicans regard the Maroons, which they attribute to the betrayal of Paul Bogle, by saying that, for the post-treaty Maroons, "[t] he basis for mere sentimental solidarity had been destroyed." 18 While creating a narrative of betrayal does not greatly illuminate Maroon history, neither does a reticence to regard and discuss those elements of Maroon history which appear less than heroic.

Archaeological data and primary documents, though spotty and plagued by the same biases as the contemporary secondary literature, are important sources, as the oral traditions are often distorted through feedback, the contemporary secondary literature is often thinly veiled colonial propaganda, and the more modern secondary literature sometimes seems to reflect more on the desires of the authors than on the history of the Maroons. Archaeologists first located the important Old Nanny Town settlement in 1967, and did not begin in-depth excavation until 1991. ${ }^{19}$ This excavation of Nanny Town and other excavations in Accompong were conducted with the help of the Maroons and the consent of the Maroon colonels and governing councils. The expressed purpose of this work was to "determine the nature and mechanism of functional adaptation of Maroon communities in the New World over time - a search for a cultural history rather than a history of 'rebels' or a second-rate group of people." 20 While interpretation of archaeological data is certainly not free of the interpretational biases that affect other forms of historical inquiry, it can be useful to analyze the material remains of a culture while remaining mindful of the interpretive biases and shortcomings of others.

Other important anthropological research considering the Maroons includes the ethnohistorical work by Barbara Klamon Kopytoff. Kopytoff wrote her 1973 doctoral dissertation, “The Maroons of Jamaica: An Ethnohistorical Study of Incomplete Polities, 1655-1905,” in an

\footnotetext{
${ }^{17}$ Maroon Heritage, ed. E. Kofi Agorsah (Kingston, Jamaica: Canoe Press, 1994).

${ }^{18}$ Carey Robinson, "Maroons and Rebels (A Dilemma)," in Maroon Heritage, ed. E. Kofi Agorsah (Kingston, Jamaica: Canoe Press, 1994): 86.

${ }^{19}$ E. Kofi Agorsah, "Archaeology of Maroon Settlements in Jamaica,” in Maroon Heritage, ed. E. Kofi Agorsah (Kingston, Jamaica: Canoe Press, 1994): 165.

${ }^{20}$ Agorsah, "Archaeology of Maroon Settlements in Jamaica," 165.
} 
attempt to demolish the view of Maroons as "social survivals, as isolated islands of 'archaic' African cultures preserved under unique 'tribal' conditions." 21 Kopytoff endeavors to use written historical records as an ethnographer uses testimonies by and observations of living people; though the results are more useful than the shrill narratives of resistance and betrayal, Kopytoff's work is characterized by a narrow focus on the impact of leaders on history. This top-down approach, which Kopytoff indicates was suggested "in the course of gathering oral data on the 'traditional' maroon political system [where] the chronic problem of Maroon leadership emerged as central issue," detracts from the agency and importance of everyday Maroons and their decisions in effecting the course of history. ${ }^{22}$ While leadership issues are a worthy consideration in Maroon history, historians have largely abandoned the privileging of the history and importance of the elite.

Ethnomusicologist Kenneth Bilby effectively uses the techniques of cultural anthropology to unpack the meaning behind various symbols and myths in the Maroon culture. His work is free of the conflation of Maroon with Rasta, and he does not adopt a narrative of resistance and subsequent betrayal. His extensive fieldwork amongst the Maroons, and the openness with which he engaged in their ceremonies and rituals, yields a much more thorough understanding of Maroon culture than that achieved by other scholars. ${ }^{23}$

While a critical re-appraisal of the theoretical and cultural biases underlying the current works on Maroon history is clearly necessary, so, too, do the difficulties associated with the scant first-hand data and secrecy and initial aliteracy of the Maroons demand reconsideration. Maroons were not, historically, literate, and literacy came to the Jamaican Maroons at the hands of Christian missionaries; such an education extends far beyond orthography and phonics into the most intimate realms of self-perception, identification, and values, as evinced by the writings of many missioneducated Africans. Even postcolonial Jamaica has threatened Maroon autonomy, as governments have questioned the validity of treaties made with the erstwhile colonial power. The emancipation of slaves in Jamaica, too, orchestrated greater contact between Maroons and non-Maroons on the island, and this contact brought further changes in Maroon communities. These influences on the oral tradition, combined with the previously discussed issues of feedback, make ethnographic research a tenuous gateway into an understanding of the eighteenth-century Maroons. Many

\footnotetext{
${ }^{21}$ Barbara Klamon Kopytoff, “The Maroons of Jamaica: An Ethnohistorical Study of Incomplete Polities, 16551905” (Ph.D. diss., University of Pennsylvania, 1973), xxvi.

${ }^{22}$ Kopytoff, The Maroons of Jamaica, xxxi.

${ }^{23}$ Kenneth Bilby, "Swearing by the Past, Swearing to the Future: Sacred Oaths, Alliances, and Treaties among the Guianese and Jamaican Maroons," Ethnohistory 44 (Fall 1997): 10-25.
} 
archival resources from the eighteenth century are in extreme disrepair, and some important documents are sealed shut with mold, crumbling, and otherwise inaccessible to researchers at the National Archives in Jamaica. Those documents that are available present a frustratingly shallow and one-sided depiction of the Maroons.

Thus, anyone seeking to create a nuanced history of the Jamaican Maroons is forced to rely on a great deal more conjecture and analogical comparison than any historian would wish to do. These difficulties, combined with the cultural and relative physical inaccessibility of Maroons, account, perhaps, for the comparative dearth of thoughtful scholarship on Maroon history. While answers may never be apparent or conclusive, questions about the Jamaican Maroons are certainly worth asking. Jamaican Maroons captivate the imagination of many, and can be inspirational in a way that does not necessitate anachronistic projection or sentimental over-romanticizing. The military strategies of the Maroons are widely credited as representing the first successful guerrilla campaigns in the New World, and scholars have exhaustively studied the Maroons' guerilla tactics. What is less examined, and perhaps less easily rendered into epic prose, is the rapid and thorough transformation of an tremendously diverse assortment of unrelated fugitives into a coherent and cohesive ethnicity. The ethnogenesis of the Jamaican Maroons, necessitated by the bitter struggle against the British, occurred within the period of one, or perhaps two, generations. The story of that process, and the social, spiritual and psychological machinations that made it possible, is the subject of this work.

\section{THE ORIGINS OF THE PROTO-MAROONS IN AFRICA}

As African cultural traditions have been an area of intense focus for scholars studying the Maroons, much effort has gone into attempting to ascertain the specific areas and cultural complexes in Africa from which the Jamaican Maroons derive. One way of narrowing the focus to specific African cultures is to analyze slave ship records for ports of origin, though records are notoriously incomplete and ports of departure for Africans do not necessarily reflect point of origin. Many enslaved in Africa were captured at points far distant from those at which they were sold. However, for all ships disembarking in Jamaica between 1676 and 1700, of the 55,776 slaves that arrived during these years, of those for whom ports of origin in Africa are known, 5,414, or 11.2\%, originated from the Gold Coast. Between 1701 and 1725, 29,912 of 125,338 disembarked slaves, 
$44.8 \%$ of the total enslaved population for whom a port of embarkation was recorded originated from the Gold Coast. ${ }^{24}$

The British believed that various African people possessed different innate physical and social characteristics, and the role of the Kromantis, also known as Coromantee, Cromantin, Kramanti and Koromanti, played is crucial to understanding eighteenth-century Jamaica. All of these terms are orthographic variations on the same pseudo-ethnic identity created by the British to refer to those who embarked on slave ships from around the area of the Akan fishing village on the Gold Coast, Kromantine. ${ }^{25}$ Edward Long claimed, " $[t]$ he Coromantins, and many others of the Gold Coast slaves, are haughty, ferocious, and stubborn. The Minnahs, timind [sic] and desponding, apt to destroy themselves upon the least, and often without any, provocation. The Mundingo Negroes are very subject to worm disorders; the Congos to dropsies." 26 According to Dallas, "the Coromantee [are] are a people inured to war on the coast of Africa."27 The British believed that the Kromanti possessed "superior strength... and greater hardiness to support field labour," which made them more appealing to sugar planters. ${ }^{28}$ Indeed, the British appeared to have greatly admired the Kromanti. In 1701, Christopher Codrington, British governor of the Leeward Islands, wrote of the Kromanti that " $[\mathrm{t}]$ hey are not only the best and most faithful of our slaves, but are really all born Heroes. There is a difference between them and all other Negroes... There was never a rascal or a coward of yt nation, intrepid to the last degree." 29 The majority of enslaved Akan speakers taken to the Caribbean appear to have disembarked in Jamaica. ${ }^{30}$ However, after a series of Kromanti-led slave revolts in the 1760s, the Assembly of Jamaica contemplated a bill "for laying an additional higher duty upon all Fantin, Akim, and Ashantee Negroes, and all others commonly called Coromantins, that should, after a certain time, be imported, and sold in the island." 31 The bill did not pass, and Kromantis continued to be associated with most of the major slave revolts in Jamaica.

Further evidence for this Akan derivation of the core of the Jamaican Maroons lies in linguistic and cultural continuities observed since the eighteenth century. The blood ritual which

\footnotetext{
${ }^{24}$ David Eltis et al., eds., The Trans-Atlantic Slave Trade: A Database on CD-ROM (Cambridge, UK: Cambridge University Press, 1999), query and summary of slaves disembarking in Jamaica between 1676-1700 and 1701-1725.

${ }^{25}$ Zips, 55.

${ }^{26}$ Long, 405 .

${ }^{27}$ Dallas, 29.

${ }^{28}$ Long, 471.

${ }^{29}$ Codrington to Council of Trade and Plantations, 30 December 1701, quoted in Mavis Campbell, The Maroons of Jamaica, 1655-1796: A History of Resistance, Collaboration and Betrayal (Massachusetts: Bergin and Garvey Publishers, 1988), 45.

${ }^{30}$ Philip Curtin, The Atlantic Slave Trade: A Census (Madison, WI: University of Wisconsin Press, 1969), 161.

${ }^{31}$ Long, 470 .
} 
sealed the Leeward Treaty of 1739 is known as "The Asante Oath," though, as previously mentioned, Twi-speakers could have been slaves of the Asante or other Akan speakers, or simply people from the Akan hinterlands who spoke Twi, a widely distributed language. ${ }^{32}$ One version of the oral history of Nanny in Maroon communities explains that far from ever having been a slave herself, Nanny was an Asante queen, who, knowing that her people were in trouble, voluntarily resettled in Jamaica. ${ }^{33}$ Similarities between words in the Kromanti language, which, according to a former colonel of the Moore Town Maroons, "is regarded as a hybrid having Twi, the Ashanti language of the Gold Coast... as the more vigorous of its parents," and Twi as spoken in Ghana are abundant. $^{34}$ Prominent Maroon names, such as Kofi, Kojo, and Quaco, which dominate the Accompong Maroon census of 1773 (the only year in which the names of the Maroons were entered into the Journals of the Assembly of Jamaica), are consistent with the Akan practice of naming a child after the day of the week on which she or he is born. ${ }^{35}$ Other strong evidence for Akan influence lies in names and specific practices. Daukunu, a maize dish, is prepared the same way and called by the same name in Ghana and amongst the Jamaican Maroons. ${ }^{36}$ Other examples of such mutually intelligible words include the deity name "Nyankopong...unsu (water), unsa (rum), edwiani (food), kwedu (banana), ekutu (orange), and prako (pig)."37 Amongst Jamaican slaves as a whole, Akan (or the version known as Twi) became a prominent and widely used lingua franca, and even slave masters used words from Akan. ${ }^{38}$ While elements of Kromanti language, including lexicon, inflection, and grammar, remain central to the Jamaican creole spoken by modern Maroons, Kromanti has largely become a ritual language, used in certain rituals and in the Kromanti Play.

Kromanti Play is a ritual ceremony, often conducted for the purposes of healing. The Play involves drumming and singing, and possession of one of the Maroons present by the spirit of one of the ancestors. ${ }^{39}$ Ethnomusicologist Kenneth Bilby attended a Kromanti Play in the 1970s after participating in a version of the famed "Asante oath." This oath, which will be discussed later, is

\footnotetext{
${ }^{32}$ M. Campbell, 115.

${ }^{33}$ Karla L. Gottlieb, “'The Mother of Us All”" A History of Queen Nanny, Leader of the Windward Jamaican Maroons, (Trenton, NJ: Africa World Press, Inc., 2000), 70.

${ }^{34}$ C.L.G. Harris, “The True Traditions of My Ancestors," in Maroon Heritage, ed. E. Kofi Agorsah (Kingston, Jamaica: Canoe Press, 1994), 39.

${ }^{35}$ Journals of the Assembly of Jamaica, 16 November 1773.

${ }^{36}$ Maroon Heritage, xv.

${ }^{37}$ Harris, 42.

${ }^{38}$ John Thornton, Africa and Africans in the Making of the Atlantic World, 1400-1680 (New York: Cambridge University Press, 1992), 192-205.

Trevor Burnard, Mastery, Tyranny, and Desire: Thomas Thistlewood and His Slaves in the Anglo-Jamaican World (Chapel Hill, NC: The University of North Carolina Press, 2004), 4.

${ }^{39}$ Harris, 49 .
} 
central to the Maroon conception of identity, and of the sanctity of the Peace Treaties. ${ }^{40}$ Kromanti Play and the Asante oath both reflect cultural continuities with the Akan-speaking regions of the Gold Coast.

Either because of the numerical preponderance of Akan-speaking or Kromanti-associated people in the Maroon groups, or because of their prominence, elements from these cultures are most observable amongst the Jamaican Maroons. Other African groups, however, were undoubtedly part of the Maroons. British descriptions of captured Maroons include such monikers as Congo and Igbo, and "the advertisements for runaway slaves, who swelled the membership of the bands, include all...types."41 One notable non-Akan ethnicity represented in the Jamaican Maroons is Madagascan.

Dallas described this element of the Maroons as "distinct in every respect; their figure, character, language, and country, being different from those of the other blacks... They were called Madagascars, but why I do not know, never having heard that any slaves were brought from the island of Madagascar." Historical records show that Europeans purchased slaves in Madagascar as early as the sixteenth century, and export of slaves across the Atlantic increased as the demand for slaves to work sugar plantations increased. ${ }^{43}$ The Madagascan element amongst the Maroons, according to one source, were descended from survivors of a slave ship that wrecked off the Jamaican coast in 1670. ${ }^{44}$ Dallas claimed that the Madagascans "ran away from the settlements about Lacovia, in the parish of St. Elizabeth, soon after the Planters had bought them."45 Initially, the Madagascans had their own leader, and often raided plantations or helped plantation slaves flee, thus increasing their numbers. When the leader of the separate Madagascan group died in battle, these numerous fugitives joined Kojo's band and accepted his leadership. ${ }^{46}$

\section{FROM SLAVES TO KROMANTIS}

\footnotetext{
${ }^{40}$ Bilby, "Swearing by the Past," 664.

${ }^{41}$ Kopytoff, The Maroons of Jamaica, 22.

${ }^{42}$ Dallas, 31-2.

${ }^{43}$ Gwyn Campbell, "Madagascar and the Slave Trade, 1810-1895," The Journal of African History 22 (1981): 205.

${ }^{44}$ Orlando Patterson, The Sociology of Slavery: An Analysis of the Origins, Development and Structure of Negro Slave Society in Jamaica (Rutherford, N.J.: Fairleigh Dickinson University Press, 1969), 268.

${ }^{45}$ Dallas, 32.

${ }^{46}$ M. Campbell, 46-7.
} 
An important step in the creation of a Jamaican Maroon ethnicity was the coalescing of the various Akan speakers into a Kromanti identity. The mutual intelligibility of the various Akan dialects greatly expedited this process. In addition, the shared experience of the Middle Passage and the plantation facilitated social cohesion. The kinship system of the Saramaka Maroons of Suriname, analogously, is centered on matriclans that often trace their origins to people who shared the Middle Passage and fled from the same plantation. ${ }^{47}$ The core of the Leeward Jamaican Maroons derived from a group of four hundred slaves who revolted on Sutton's plantation in Clarendon in 1690 and fled to the Cockpits. ${ }^{48}$ The leader of the Clarendon rebels was Kojo's father. $^{49}$

This strong nucleus of Clarendon rebels in the West encountered a fragmented sociopolitical situation in the Cockpits. Though some of the refugees maintained contact with those on plantations, many, particularly women, the elderly, and the young, who were not involved in regular raids, were cut off from contact with family and friends on the plantations. Furthermore, the Clarendon rebels entered an area that already abounded with refugees. The Madagascans, previously mentioned, occupied the same region of the Cockpit country of St. Elizabeth's perish, and, indeed, fought with Kojo's group until the demise of their leader. Other bands consisting of members of past slave rebellions, including, notably, participants in a 1673 rebellion on Lobby's plantation, found refuge in the Cockpits, and a 1685 rebellion on Widow Grey's plantation augmented the Windward group, who were, generally, more reticent to accept newcomers. ${ }^{50}$ Most of these rebellions are described in the colonial documents as being led by Kromantis. Other than these rebel groups, many other individuals and smaller groups simply fled the plantation and congregated in larger bands in the interior.

The groups in the Windward part of the island were largely derived from enslaved people who seized the opportunity presented by the British capture of Jamaica from the Spanish in 1655 to flee into the Blue Mountains. ${ }^{51}$ Dallas marveled at the existence of such groups as, in his opinion, "slaves are often found faithful to their owners, and hostile to invaders." 52 Though the British continued to worry that these fugitive slaves would help re-conquer the island for the Spanish, of more immediate concern was the "perpetual alarms [caused by] setting fire to buildings... and...even

\footnotetext{
${ }^{47}$ R. Price.

${ }^{48}$ Dallas, 23.

${ }^{49}$ Kopytoff, The Maroons of Jamaica, 29-30.

${ }^{50}$ Kopytoff, The Maroons of Jamaica, 29.

${ }^{51}$ Agorsah, "Archaeology of Maroon Settlements in Jamaica," 165.

${ }^{52}$ Dallas, xxxi.
} 
to houses in the capital itself...they actually intercepted and massacred without pity, almost every individual who ventured to ramble into the country." 53 Many of these early refugees were Spanish creoles, though Akan-speakers seemed prevalent both in this group and amongst the later fugitives and rebels who joined them. ${ }^{54}$

In the late seventeenth and early eighteenth century, Akan-speaking states were anything but unified and cohesive. Asante, perhaps the most powerful of the states, was engaged in massive military expansion efforts against its neighbors as it sought to dominate both the gold and the slave trade. $^{55}$ Between 1670 and 1744, Asante engaged in wars of conquest against Kenkyrira, Banda, Gyaman, Akyem, Akwapim, and Akwamu, all Akan-speaking polities. ${ }^{56}$ In fact, the various wars in which the majority of the slaves sold from the Gold Coast had been captured are telling indicators of the high degree of conflict amongst the Akan-speaking states. Thus, the designation of Akanspeakers as Kromanti, a practice which originated with the slave traders, had great significance in the transformation of the disparate groups of refugees in the Jamaican interior into the Jamaican Maroons.

Much has been written about the physical and psychological debasement inherent in the dehumanizing practices of the Middle Passage and of plantation slavery. A crucial aspect of this process, which is often overlooked, is the spiritual tactics used by the slave traders against the enslaved Africans. In some places, "the slave was made to take an oath of allegiance to his enslaved status while cracking a cola nut...Slaves were also tamed with drugs... [and in Muslim areas, slaves were] washed in water mixed with talismans based on Koranic verses." ${ }^{57}$ In Dahomey, enslaved people were forced to walk around "the tree of forgetfulness" in a sacred grove; this process was designed to make the people forget who they were, and it reportedly produced immediate, observable docility amongst many subjected to this ritual. ${ }^{58}$ In conjunction with the physical and psychological torture to which enslaved people were subjected, this spiritual violence profoundly affected self-perception.

The proto-Maroons, then, needed a powerful weapon with which to combat this spiritual assault, a weapon on par with their mastery of guerilla warfare tactics. This spiritual weapon took

\footnotetext{
53 Dallas, xxxii.

${ }^{54}$ M. Campbell, 47-8.

55 T.C. McCaskie, State and Society in Pre-Colonial Asante (Cambridge: Cambridge University Press, 1995), 25-6.

${ }^{56}$ Robert W. July, A History of the African People, $5^{\text {th }}$ ed. (Prospect Heights, IL: Waveland Press, 1998), 124-5.

${ }^{57}$ Djibril Tamsir Niane, “Africa’s Understanding of the Slave Trade: Oral Accounts,” Diogenes 45 (1997): 85.

${ }^{58}$ Laura Samsom Rous and Hans Samsom, Tree of Forgetfulness (Amsterdam: Koninklijk Instituut Voor de Tropen, 2004).
} 
the form of the "Asante oath." This oath appears figures most prominently in the Maroon assertion that the peace treaties were sealed with a blood oath. However, members of the early group were also made to swear a version of the Asante oath as an oath of incorporation. ${ }^{59}$ In 1733 , a captured Maroon reportedly told the British

they [the Windward Maroons] give encouragement for all sorts of negroes to join them, and oblige the men to be true to them by an oath that is held very sacred among the negroes, and those who refuse to take the oath, whether they go of their own accord or are made prisoners, are instantly shot to death. ${ }^{60}$

Bilby is able to trace discrete elements of the oath of incorporation to exactly corresponding oaths prominent in Asante and in Akan-speaking groups that conflicted with the Asante. ${ }^{61}$

Accounts of the blood oath pervade from other colonial interactions with Maroon groups. The Aluku Maroons of Suriname and French Guiana treated with the French emissary Cadet in 1780. After initial suspicion, the Aluku agreed to peace, and sealed the offer "with blood drawn from both their arms and mixed together in a calabash, from which both men drank."62 A similar account of the blood oath was written by the French priest Nicolas Jacquemin, who negotiated with the Aluku in 1782. Jacquemin relates:

They [the Maroons] said that it would be necessary to cement the alliance with an oath commonly used among them; as I knew what this oath consisted of, I showed repugnance, saying that it wasn't necessary...A negro put some water in a calabash and then lightly pricked Jacquet [Father Jacquemin's companion] on his foot and on his hand with the point of a knife and drew a drop of blood, which he put in the calabash. After this he did the same thing to the negro captain, then put in the said calabash a bit of ashes and earth and mixed it all together. Then the chief spoke, saying that this ceremony, this mixing of our blood with theirs, signified that we had become brothers, that we must always be as one with them, and they with us, making a thousand curses against those who would violate this pledge, wishing that they be

\footnotetext{
${ }^{59}$ Bilby, "Swearing by the Past," 670.

${ }^{60}$ Barbara Klamon Kopytoff, “The Development of Jamaican Maroon Ethnicity,” Caribbean Quarterly 22 (1976): 44.

61 Bilby, "Swearing by the Past," 676.

${ }^{62}$ Bilby, "Swearing by the Past," 664.
} 
anathema... $[\mathrm{A}]$ negro took a bit of the mixture that was in the calabash and poured it twice into their mouths. ${ }^{63}$

Bilby reports a similar practice amongst other Maroon groups, including the Saramaka, Matawai, and Ndjuka of Suriname, and traces the origins of such practices to oath swearing amongst Akan. ${ }^{64}$ The oaths constituted an important cultural continuity that may have been Akan in derivation, but was seemingly understood and respected by all the proto-Maroons. This oath consecrated the terms of the treaties with the same gravity that was attributed to all oaths sworn in the witness of the gods. Indeed, other permutations of the oath ritual were, and still are, performed any time a non-Maroon witnesses an important Maroon ritual, such as the Kromanti Play. ${ }^{65}$ By delineating membership in the community by allegiance to a sacred oath sworn to the gods, the heterogeneous Akan-speakers and non-Akan were able to create a clear sense of solidarity. That this oath derived from the Asante would have important ramifications.

Using this kind of oath solidified people into Kromanti-identified, and, ultimately, Maroons. Kojo appears largely instrumental in this process, at least for the Leeward Maroons. Significantly, Kojo forbade the use of any language other than English, seeking to avert ethnic factionalism. ${ }^{66}$ Though English may have been the mandated language of use, Kromanti persisted. Even today, Kromanti is known as a ritual language, and elements of Kromanti are present in the every day speech of modern Maroons. Though Kromanti was allowed to persist, other African languages were not. Dallas reports that some Maroons in the late eighteenth century remembered words and phrases from different African languages, spoken by their parents, including Malagasy. ${ }^{67}$ Kromanti was never an ethnic designation for Africans; in the crucial period between 1655 and 1739, however, Kromanti became a critical identity in Jamaica. It would not be until the signing of the 1739 treaties that Kromanti identity would be replaced by a Maroon identity.

\section{BRITISH CONCEPTIONS OF RACE AND ETHNICITY}

\footnotetext{
${ }^{63}$ Nicolas Jacquemin, “Journal de Mon Voyage Chez les Indiens et les Negres Refugies sur Nos Terres, Fait en Decembre 1782“ reproduced in Jean Hurault, "Histoire des Noirs Refugies Boni de la Guyane Française (d'Après les Documents des Sources Françaises)," Revue Française d'Histoire d'Outre-Mer 47 (1960): 98-101, translated in Bilby, "Swearing by the Past."

${ }^{64}$ Bilby, "Swearing by the Past," 668-73.

${ }^{65}$ Bilby, "Swearing by the Past," 674-7.

${ }^{66}$ Kopytoff, The Maroons of Jamaica, 26.

${ }^{67}$ Dallas, 32-3.
} 
Intrinsic to the British regard of the proto-Maroons and Maroons, was the larger conceptual rubric under which the Europeans understood race. During the seventeenth and early eighteenth century, before Enlightenment philosophy was firmly embedded in European culture and led to the advent of scientifically justified racism, one construct for explaining racial differences was the Hamitic hypothesis. The origin of the Hamitic hypothesis lies in the Babylonian Talmud of the sixth century CE; the Talmud is a collection of a Jewish oral tradition regarding interpretation of the Torah. One section of the Babylonian Talmud seeks to elaborate on Genesis 9:24-25, wherein "Noah awoke from his wine, and knew what his younger son [Ham] had done unto him [in laughing at his father's drunkenness and nakedness]. And he said, Cursed be Canaan; a servant of servants shall he be unto his brethren." ${ }^{68}$ In explaining this section of Genesis, the Babylonian Talmud claims that "the descendants of Ham are cursed by being black...[and are]...sinful...and...degenerates." ${ }^{69}$ This myth became particularly utilitarian for the Christians in the late mediaeval period, during which time labor shortages caused by the high death rate of the bubonic plague increased the need for forced labor. ${ }^{70}$ Finding a biblical explanation for the innate inferiority of an entire continent of people eased the Christian conscience and made the profitable practice of slavery, though by no means restricted to Africans, entirely feasible for legions of pious seventeenth-century Europeans.

The Hamitic hypothesis represents an early, broad European mythical construct used to understand race. The British, however, had more specifically evolved racial constructs which informed their thinking by the eighteenth century. Anglo-Saxon racial consciousness originated in the sixteenth century English split with the Roman church; Anglican Archbishop Matthew Parker and others, in working to justify the divergence from Rome, focused attention on English practices that predated the Norman conquest. ${ }^{71}$ As linguistic studies emerged, Anglo-Saxon identity was subsumed under the larger Teutonic myths, as promoted by Verstegan, Camden, and others in the seventeenth century. Teutonic peoples were glorified as liberty-loving; the contemporary English viewed the Teutonic campaigns against a decaying and decrepit Rome as the racial antecedent to the

${ }^{68}$ Genesis 9:24-25. King James Version.

${ }^{69}$ Edith R. Sanders, “The Hamitic Hypothesis: Its Origin and Functions in Time Perspective," Journal of African History 10 (1969): 521-522.

${ }^{70}$ Robert Graves and Raphael Patai, Hebrew Myths: The Book of Genesis (Garden City, NY: Doubleday, 1964), 121.

${ }^{71}$ Reginald Horsman, "Origins of Racial Anglo-Saxonism in Great Britain Before 1850," Journal of the History of Ideas, 37: 3 (July-Sept. 1976), 387-88. 
freedoms sought by the British in sixteenth- and seventeenth-century reforms. ${ }^{72}$ Eighteenth-century British racial consciousness had departed from a broader, more generalized Biblical paradigm, embracing instead an ideology that uniquely glorified the Teutonic peoples. According to Horsman, "[e]ighteenth-century English Whigs and radicals accepted as axiomatic the view that English political institutions had enjoyed a continuous history from Saxon times, and that subsequent changes had destroyed earlier freedoms.",73

Later eighteenth-century thinkers were to bind notions of race to conceptions of national identity as defined by language. For example, John Pinkerton's famous 1787 publication, Dissertation on the Origin of the Scythians or Goths, proclaims "A Tartar, a Negro, an American \&c. \&c. differ as much from a German, as a bull-dog, or lap-dog, or shepherd's cur, from a pointer," with no greater fervor than his description

of Celts as "savages since the world began, and will be for ever savages while a separate people; that is, while themselves, and of unmixt blood." 74 To the eighteenth-century British, the pre-eminence of the British Empire derived, in no small part, from the gloriousness of the Anglo-Saxon past and the English language as a most venerated member of the Germanic language family. However, the superiority of English speakers could not be conferred upon all of those who spoke English. In a footnote in the 1753-4 edition of his essay "Of National Characters," philosopher David Hume compares an educated Afro-Jamaican man to a parrot: able to generate learned-sounding phrases without possessing true intelligence. ${ }^{75}$ While eighteenth-century British subjects certainly displayed a racial consciousness, it was a fluid, nationalistic consciousness, not yet solidified into the later Blackand-White dialectic. Despite the flexibility that could allow Teutonic enthusiasts to dismiss Africans and Celts with the same broad brushstroke, by the eighteenth-century, British Jamaicans espoused a belief that Africans had "as great a Propensity to Subjections, as we have to command and love Slavery as naturally as we do Liberty.",76

British racial conceptions provided a durable circle of tautology during the seventeenth and eighteenth centuries. On one hand, all children of Ham were destined to be slaves because of continued culpability for the transgressions of Ham against Noah; all such cursed children were

\footnotetext{
${ }^{72}$ Horsman, 389.

${ }^{73}$ Horsman, 390.

${ }^{74}$ John Pinkerton, A Dissertation on the Origin and Progress of the Scythians or Goths Being an Introduction to the Ancient and Modern History of Europe (London, 1787), 24-31, 33-4, 51, 69.

${ }^{75}$ Felicity A. Nussbaum, The Limits of the Human: Fictions of Anomaly, Race, and Gender in the Long Eighteenth Century (New York: Cambridge University Press, 2003), 136-137.

${ }^{76}$ Guillaume Raynal, A Philosophical and Political History of the Settlements and Trade of the Europeans in the East and West Indies, 5 vols., translated by J. Justamond (Dublin, 1779), 5:48.
} 
marked by dark skin pigmentation. Thus, to the mind of a British subject of the seventeenth or eighteenth century, the very possession of dark skin was indicative of a natural condition of subjugation. Maroons were certainly not Germanic, but the act of maroonage displayed a love of liberty that closely cohered to the most glorified ostensible innate attributes of the Germanic people. Furthermore, Maroons ably communicated in English, particularly after Kojo's mandate of English as the official Maroon language. In engaging in maroonage, the Maroons forced the British to contend with the cognitive dissonance implicit in the witness of people refusing the life into which the British believed they had been divinely and naturally, and culturally, ordained.

The British responded to the conceptual challenge presented by proto-Maroons and maroonage by altering their theoretical constructs, or by altering their perception of events to cohere to hopelessly inadequate schemata. Given the schematic categories available to the British at the time, for example, an independent Black woman constituted an impossible reality; to be Black meant to be naturally servile, and to be a woman compounded this. While the British were able to comprehend the threat presented by the male Maroons warriors, the power of Nanny was completely incomprehensible. British Jamaicans were far more accustomed to viewing Black women as a threat only in a sexual sense. Long decried the "scheming black Jezebels... [who engaged the White men in] goatish embraces."77 Indeed, British writers attempted to diffuse the threat of the belief by many Maroons and non-Maroons that Nanny could catch bullets by moving the myth onto more familiar, erotic territory, having Nanny instead catch bullets with her buttocks. ${ }^{78}$ Though Nanny was thus degraded in the British rendering of her legends, the British also deeded the Windward Maroons land in her name under a law that was designed to encourage White settlement in Portland. ${ }^{79}$ By legally rendering Nanny a White woman, the British were able to keep their cognitive categories intact. This perceptual contortion foreshadowed the development of a later incarnation of the Hamitic hypothesis.

As the Europeans made more discoveries about African societies and cultures, particularly after the Napoleonic invasion of Egypt in 1798, certainty in the technological and cultural inferiority of all non-European cultures became an increasingly untenable position. ${ }^{80}$ Whereas the earlier version of the Hamitic hypothesis argued that all of the children of Ham were cursed with dark skin

\footnotetext{
${ }^{77}$ Long, 279.

${ }^{78}$ Kamau Brathwaite, "Nanny, Palmares and the Caribbean Maroon Connexion," in Maroon Heritage, ed. E. Kofi Agorsah (Jamaica: Canoe Press, 1994), 120-21.

${ }^{79}$ Land Patent to Nanny, 1740, British Patents Volume 22, Folio 15B.

${ }^{80}$ Sanders, 524.
} 
and eternal servitude, the hypothesis later contended that the other sons of Ham, namely Mitzraim (viewed as the forefather of the Egyptians) and Cush, were immune from the curse, which had been directed specifically at Canaan. ${ }^{81}$ This reconfiguration of the Hamitic hypothesis allowed the Europeans to account for the advanced civilization of the Egyptians; it also allowed European colonialists to claim the superiority of groups such as the Tutsis of Rwanda, who, according to the restructured myth, were actually "Caucasoid" Hamites, descendent of the non-cursed sons of Ham, rather than the doomed descendents of Canaan. In establishing a conceptual framework for claiming the superiority of certain Black groups, the Europeans were able to create a hierarchy within a hierarchy. This structure ensured an almost constant struggle between various groups of subjugated people, who scrambled to achieve Hamitic stature on the Great Chain of Being as conceived by the Europeans. The work of the British to re-configure Nanny into a privileged landed White, to restructure the militarism of the Maroons into a deadly, effective, slave-catching force, and to change the economic communalism of the Maroons into capital-seeking individualism, microcosmically reflects a larger pattern of colonial divide-and-conquer modus operandi. Nanny's seemingly miraculous shift from Black to White at the drop of a land patent represents the relative fluidity of racial characterization during the eighteenth-century. As Felicity Nussbaum argues in The Limits of the Human: Fictions of Anomaly, Race, and Gender in the Long Eighteenth Century:

In this historical period biological markers are not yet firmly fixed to nation or physiognomy, and the easy slippage from one color to another, from one place of origin to another, testifies on the one hand to an Enlightenment wish paradoxically to claim the inherent "whiteness" of all humankind and the inadequacy of pigmentation and physiognomic traits in revealing character; and on the other, the wish to formulate a philosophical basis that could justify interracial libertinism, the slave trade, and an empire. ${ }^{82}$

Nanny represented a crucial figure to the interests of the British and Maroons alike. To Maroons, both past and present, Nanny is a revered ancestor and admirable hero. To the British, Nanny served other vital functions. In deeding the Windward lands to Nanny and her followers, personally, the British blatantly disregarded the African tradition, upheld by the Maroons, of owning land corporately. To the same degree that the language of the land deed reveals the struggles of the eighteenth-century British to formulate a coherent philosophy of race and justice, it also illuminates

\footnotetext{
${ }^{81}$ Sanders, 526-7.

${ }^{82}$ Nussbaum, 156.
} 
an early attempt by the British to bring the threateningly anomalous Maroons into the comfortable and controllable realm of acquisitive individualism. Significantly, in the Maroon Land Allotment Act of 1842, the British government attempted to revoke the rights of the Maroons guaranteed in the peace treaties. This law sought to re-appropriate collectively owned Maroon lands and reapportion them to individual Maroons. Due to British unwillingness to engage in the intense military involvement enforcement of this law would have required, the Maroon Land Allotment Act of 1842 was effectively nullified. ${ }^{83}$

\section{MAROON AND BRITISH CONCEPTIONS OF LIBERTY AND THE PEACE TREATIES OF 1739}

Fundamental to the European Enlightenment thinking of the eighteenth century was the concept of endemic, bourgeois, individual freedom; indeed, the American Declaration of Independence synthesized and reiterated the most prevalent contemporary elements of political philosophy. ${ }^{84}$ Eighteenth-century European philosophers eloquently engaged with notions of liberty, freedom, and justice within the glaringly paradoxical confines of societies built upon slave labor and the trans-Atlantic traffic in African people. Throughout the European-colonial dominated world of the eighteenth century, Whites daily negotiated the obvious contradiction between their professed love of liberty and their enslavement of other human beings. The British colony of Jamaica, in particular, compelled fascinating philosophical, logical, and ethical contortions on the part of its White inhabitants. In the broader British Empire, Jamaicans were reputed to have, as early nineteenth-century observer Reverend Richard Renny described, a "high spirit of independence...[they speak] what they think, without fear or reserve...No people were more free than themselves or more watchful of their freedoms. They pay the most vigilant attention to every circumstance which can encroach upon their liberty." 85

\footnotetext{
${ }^{83}$ Zips, 118-9.

${ }^{84}$ Pauline Maier, American Scripture: Making the Declaration of Independence (New York: Random House, 1998), xvii.

${ }^{85}$ Richard Renny, A History of Jamaica (London, 1807), 209.
} 
By contrast, such a diligent maintenance of the proscriptive structures of freedom for the British of Jamaica necessitated an equally conscientious suppression of the Afro-Jamaicans. According to British Colonial Office statistics, in 1730, Whites comprised approximately $9.8 \%$ of Jamaica's population. ${ }^{86}$ The British population was far from stable; in 1730, roughly 11\% of the British population perished, largely from "tropical fevers," a catchall term for epidemics endemic to the West Indies. ${ }^{87}$ The enormous numerical minority of the British, combined with the high degree of transience and mortality, contributed to the character of Jamaican society as a barbaric outpost where slaves were treated more brutally than in any other region of the British Empire. ${ }^{88}$ In such a setting, it is not surprising that many Africans and Afro-Jamaicans refused to accept the brutality and dehumanization directed towards them by the minority British. Rebellion, whether through direct, violent resistance, maroonage, or more subtle means, such as disruption of sugar mills, was pervasive throughout the reign of the slavemasters. The most sustained, violent rejection of the plantation system was the acts of grand maroonage that ultimately created the communities in the Blue Mountains and the Cockpit Country. Within the confines of eighteenth-century Jamaican history, in which a professedly freedom-loving group of British felt perpetually menaced by the constant terror of violence and retribution from the African and Afro-Jamaican slaves whom they brutalized, the Jamaican Maroons sit inimically outside of this apparently Manichean narrative. From one perspective, the Maroons actively resisted the institution of slavery through their ultimately successful military campaigns against the British. However, the Maroons secured not the autonomy later post-colonial scholars would desire for them, but rather liberty, as they understood it.

Clearly, the manner in which the Maroons conceived of themselves and the manner in which the British understood the Maroons was diametrically opposed. Equally important was the degree to which the Maroon and British understanding of liberty differed. A useful rubric for understanding the differences between the Maroon and British conceptions of liberty is posited by philosopher Isaiah Berlin in his essay "Two Concepts of Liberty." " In this work, Berlin demarcates between negative liberty, or the freedom from interference or restraint, and positive liberty, or power and agency. The Leeward and Windward Treaties of 1739, in this respect, became guarantors

\footnotetext{
${ }^{86}$ British CO 137/19.

${ }^{87}$ Trevor Burnard, "European Migration to Jamaica, 1655-1780," William and Mary Quarterly, $3^{\text {rd }}$ series, 53 (1996): 777.

${ }^{88}$ Burnard, Mastery, Tyranny, and Desire, 20.

${ }^{89}$ Isaiah Berlin, Four Essays on Liberty (New York: Oxford University Press, 1969) 118-72.
} 
of negative liberty for the Maroons in the eyes of the British, but sacred and vital seals of positive liberty to the Maroons themselves.

The first notable statement in both treaties is the British assertion that their negative liberty had been impinged upon by the Maroon actions. In the Windward Treaty, this claim is encoded in the reference to the Maroons as "rebellious Negroes;" same claim by describing how "Captain Cudjoe, Accompong, Johnny, Cuffee, Quaco, and several other negroes, their dependents and adherents, have been in war and hostility for several years in the past." 91 To the British, the Maroon insurgency was of concern primarily because it impeded the economic success of Jamaica, and made expansion of British settlement and cultivation infeasible; further, maroonage created a constant threat of a violent and abrupt end to the slavery system through an island-wide slave revolt. In addition to British fears of violent retribution, the prospect of such a revolt also forced the British to contemplate the end of their lucrative sugar plantations. When Governor Trelawny spoke to the Jamaican Assembly in 1737, he complained that "the Rebellious Negroes... have long infested the country, and still continue to endanger the Lives and damage the Fortunes of many Inhabitants." ${ }^{22}$ Earlier yet, in 1730, the Jamaican Board of Trade wrote to the Duke of Newcastle concerning the situation in Jamaica; the Board of Trade forecasted that the Maroons "Might come down in a Body and destroy a whole Precinct before they could be stopped (if at all) for one such alarm, thousands of slaves would joyn the Victors, All equally fond of Liberty!"93 To the British, the matter of possessing the positive liberty to prosper economically was never a question for consideration; only the lack of the negative liberty of freedom from the devastation, or fear of potential devastation, wrecked by Maroon raiders inhibited their march to material gain. So intent were the British on securing their negative liberty in the treaties of 1739 that minute detail was incorporated to ensure it. The fifth clause of the Leeward Treaty includes a provision that the Maroons "have Liberty to hunt where they shall think fit, except within three Miles of any Settlement, Crawl or Pen." 94 The thirteenth clause of the Windward Treaty similarly states "[t]hat Captain Quao, nor any of his People, shall hunt within Three Miles of any Settlement." 95 So threatening was the mere presence of Maroons to British security that the treaties go into this extensive detail keeping the Maroons at least three miles from the sites of plantocratic

\footnotetext{
${ }^{90}$ British C.O. 137/56, June 30, 1739.

${ }^{91}$ British C.O. 137/23, Trelawny to Board of Trade, March 30, 1739.

92 British C.O. 137/56, Trelawny to Newcastle, July 7, 1737.

${ }^{93}$ British C.O. 137/21, Board of Trade to Newcastle, October 7, 1730.

${ }^{94}$ British C.O. 137/23, Trelawny to Board of Trade, March 30, 1739.

${ }^{95}$ British C.O. 137/56, June 30, 1739.
} 
economic endeavors. Thus, the treaties must be viewed primarily as an attempt by the British to secure their own negative liberty. So essential was this specific negative liberty to the British that they were willing to engage in uncharacteristic acts, including participation in the sealing of the treaties with the Asante blood oath, to procure it.

To the Maroons, the treaties of 1739, and particularly the Leeward Treaty, of which an original copy is kept in Accompong, are sacred documents. Intriguingly, the Maroons possessed sufficient agency at the time of the treaty signing to force the British to seal the Leeward Treaty with the Asante oath, which "involved the drawing of blood from both the white officers and the Maroon leaders, into which rum was poured, and this mixture was drunk by both parties." ${ }^{~}$ "This oath is unbreakable within the cosmology of the Maroons. By sealing the treaty with this oath, the British were agreeing, in the minds of the Maroons, to recognize primarily the autonomy of the Maroon people. The second clause of the Leeward Maroon Treaty begins: " $[\mathrm{t}]$ hat Captain Cudjoe, the rest of his Captains, adherents and men shall be forever hereafter in perfect state of freedom and liberty." 97 To the Maroons, this was not a grant of freedom from interference by the British, but rather a long-overdue acknowledgement of Maroon power. The Maroons did not conceive of themselves as fighting for freedom from the British; even freedom from the institution of slavery was won, in the Maroon mind, in the very act of maroonage. Rather, the Maroons agreed to the treaty not only to end the unbalanced war in which the small number of Maroons would eventually be overwhelmed by the numerical and material advantages of the British, but also to have the British formally acknowledge the autonomy of the Maroons.

Indeed, the backlash infamously written into Maroon history can be read as evidence of the threat the acknowledgement of this positive liberty posed to the British. Dallas, the most oft-quoted early historian of the Jamaican Maroons, writes that:

Cudjoe...appeared to be in great trepidation...Colonel Guthrie advanced to him holding out his hand, which Cudjoe seized and kissed. He then threw himself on the ground, embracing Guthrie's legs, kissing his feat, and asking his pardon. He seemed to have lost all his ferocity, and to have become humble, penitent and abject. The rest of the Maroons, following the example of their chief, prostrated themselves, and

\footnotetext{
${ }^{96}$ M. Campbell, 115.

${ }^{97}$ British C.O. 137/23, Trelawny to Board of Trade, March 30, 1739.
} 
expressed the most unbounded joy at the sincerity shown on the side of the white people. $^{98}$

Campbell reports that modern Maroons unanimously reject this narrative. ${ }^{99}$ Other early historians who write about the Maroons, such as Long, do not include such an account. Not only is this portrayal idiosyncratically stylized to conform to a servile-coon stereotype that contemporarily justified slavery as the natural condition of innately subservient Africans, but it is completely discordant with the power Kojo obviously had in negotiating the terms of the treaty. The Maroons wielded sufficient positive liberty to retain the presence of the more recent fugitive slaves within their ranks, despite the wishes of Governor Trelawny and the Jamaican Assembly, in securing the ability of those who had been with the Maroons for fewer than two years to remain Maroons. ${ }^{100}$ Furthermore, the vivid image of the British officers being compelled to seal the treaty with the Asante blood oath compellingly denies the veracity of a genuflecting, quivering, servile Kojo. On reflection, such a grotesque image can be viewed only as an over-blown response to the threat posed by the power of the Maroons.

Another example of British efforts to prevail in the realm of symbolic representation where they had failed militarily is the distortions of aspects of the Nanny myth. The Maroons believe that Nanny, using her religious obeab powers, was capable of catching bullets. To the Maroons, this capacity represented the connection of Nanny to the spirits, and the support for and presence of the spirits for the battles in which the Maroons fought. ${ }^{101}$ According to Kamau Brathwaite, the distortion of this mythical power of Nanny's was first preserved in the written record in H.T. Thomas' Untrodden Jamaica, written in 1890. ${ }^{102}$ Terrified by the power of obeab and humiliated by military defeat at the hands of a small group of undersupplied Blacks led by a woman, the British turned the myth of Nanny-as-bullet-catcher into an obscene and lascivious tale. Under the British permutation, Nanny became renowned for being able to catch bullets in her buttocks, and return them to the British through gaseous expulsion. ${ }^{103}$ By re-imagining Nanny as a degraded, absurd, and sexually objectified woman, the British were able to assuage the discomfort and terror that accompanied an awareness of the true extent of the positive liberty of the Maroons. The sexual

\footnotetext{
${ }^{98}$ Dallas, 55-56.

${ }^{99}$ M. Campbell, 114.

${ }^{100}$ British C.O. 137/23, Trelawny to Board of Trade, March 30, 1739.

${ }^{101}$ Gottlieb, 74.

102 Brathwaite, 120-1.

103 Brathwaite, 121 .
} 
depravity of African women was a more familiar territory than the success and power of an obeah woman.

However menaced the British felt by the evidence of Maroon positive liberty, and whatever extraordinary and base measures the British were willing to enact, culturally or legally, to curtail these, the treaties still read largely as documents formed by those who unquestionably privileged negative liberty. The Leeward and Windward Treaties both go to extensive lengths to detail the rights of the Maroons to live on the lands granted to them, and to function agriculturally and commercially without interference. The treaties also ensure legal autonomy of Maroons for matters pertaining to the Maroon community. ${ }^{104}$ While the Maroons were not opposed to the negative liberty guaranteed in these clauses, the most significant and persistent aspect of the treaties to Jamaican Maroons is the evidence of positive liberty the mere existence of these treaties, and the Asante blood oath under which the Leeward Treaty was signed, connotes.

To the British, the Maroons began as troublesome cattle; after the cattle transfigured into a military force with which to be reckoned, the British simply re-analyzed the Biblical text, and reassigned the Maroons to the category of quasi-White Hamites. In this process, the British, while reluctantly and in a limited fashion recognizing the positive liberty of their foes, perceived a victory in ensuring the terms of the treaty safeguarded their own treasured negative liberty. Both Maroon and British were deeply satisfied with a treaty that seemed to accord to each party what each most cherished.

\section{MAROON FOUNDATION STORIES AND THE TRANFORMATION OF KROMANTIS INTO MAROONS}

When the Maroons secured their autonomy from the British with the Windward and Leeward Treaties, they were recognized, for the first time, as a unified social and political unit. The process of becoming such a unified society, however, was far more complex than the simple signing of a treaty. The proto-Maroons had to abandon some aspects of their home cultures, alter others, and create entirely new cultural beliefs and behaviors to emerge as a cohesive ethnicity by 1739 . Retention of specific characteristics of individual African cultures, in the forced pluralism of mountains and Cockpits of Jamaica, was untenable. Matrilineal and patrilineal societies who spoke different languages and worshipped different deities were forced to abandon old loyalties and

${ }^{104}$ British C.O. 137/23, Trelawny to Board of Trade, March 30, 1739; Windward Treaty, C.O. 137/56, June 30, 1739. 
schemata to survive. Though political factionalism has had a great impact on post-Treaty Maroons, by the mid-eighteenth century, Maroons no longer conceived of themselves as anything other than the children of Nanny. The consolidation of various ethnic identities into a Kromanti identity between 1655 and 1739 was an imperative step in the eventual transformation to Maroon. By the time the Maroons gained recognition and autonomy from Britain in 1739, their myths, stories, and cultural practices had become entirely Maroon-specific.

Central to comprehending Maroon identity is an understanding of the myths of Queen Nanny, considered by Maroons to be the progenitor of their nation. According to the Jamaican Ministry of Youth, Education, and Culture, Nanny is the only woman who is a national hero of Jamaica; she is also the only Maroon. ${ }^{105}$ Most modern Maroons assert that Nanny was never a slave. Major Charles Aarons, Deputy Chief of the Moore Town Maroons, claims, "The Maroons of Jamaica had never been slaves at any time."106 This declaration derives from the assertion that Nanny herself was never a slave, but rather an Asante queen who relocated to Jamaica with her own retinue of slaves to aid her troubled people.

The existence of an apical ancestress as the "mother of all" members of an ethnic group or clan is a tradition brought from the Akan states and other matrilineal societies in Africa. The Asante, despite their complex, centralized bureaucracy and military, lived within a social order predicated upon membership in one of a very few matriclans. ${ }^{107}$ As a child's status derived from that of her or his mother, the fact that all Maroons descend from Nanny, who was never enslaved, makes Maroon freedom a birthright. Strict matrilineality does not seem to have been retained by the Jamaican Maroons as it was by other Maroon groups, such as the Saramaka of Suriname, where each lo, or matriclan, traces its origin to a woman who fled the Dutch plantations during the First Times. ${ }^{108}$ Elements of this matrilineal descent system, however, may have persisted in the fact that in earlier times, only Maroon women were allowed to marry outsiders and bring them into Maroon lands. ${ }^{109}$ Even if the Jamaican Maroons gradually abandoned strict matrilineality as a concession to the diversity of ethnic backgrounds of the community, or due to disruptions of family and kinship systems wrought by the Middle Passage and plantation life, the centrality of Nanny to Maroon identities is likely a relic of this background. Because all Maroons identify as the children of Nanny,

\footnotetext{
105 Jamaican Ministry of Youth, Education, and Culture, Jamaica's National Heroes, 2001, $<$ http://www.moec.gov.jm/heroes/nannycont.htm> (11 May 2004).

106 Gottlieb, 67.

${ }^{107}$ McCaskie, 26.

${ }^{108}$ R. Price.

${ }^{109}$ Daniel Lee Schaefer, “The Maroons of Jamaica” (Ph.D. diss., University of Minnesota, 1973), $233 f$.
} 
the kinship metaphor is a powerful indicator of Maroon solidarity. Though Nanny may have been an Asante queen, and some proto-Maroons may have derived from states in conflict with the Asante, or from non-Akan/Kromanti backgrounds, all of Nanny's children were exclusively Maroon.

As maintained by many versions of the Nanny myth, Nanny came to Jamaica with her sister, who is variously named Sekesu, Sukasi, Sekeri, Sue, Sarah, Opinya, Nellie, or Grace. ${ }^{110}$ The myth explains the diverging history of Maroons and slaves as beginning in the split between the sisters, wherein:

the children of Nanny are said to have grown up to become the Maroon 'nation,' while those of the other sister grew up to become a different 'nation' of people whom the Maroons refer to as 'niega'-the descendants of those who were kept in a condition of slavery until the British government decided to emancipate them in $1834 .{ }^{111}$

The kinship between Maroons and non-Maroons in the sisterhood of Nanny and Sekesu is most often invoked by non-Maroons seeking spiritual or supernatural help from Maroons. ${ }^{112}$ Within the Maroons' cosmology, however, difference is the crucial component of this aspect of the Nanny myth. The Maroons view themselves as a different nation than non-Maroons.

Indeed, shortly after the signing of the 1739 treaties, the strength of this new ethnic identification would be put to the test. In 1742, some of the men in Kojo's village

had entered into a conspiracy with slaves on neighboring plantations and were inciting them to revolt. It was a group of Coromantees within Cudjoe's band and they, allied with Coromantee plantation slaves, planned to 'cast off all those there that were born in the woods, or came from other countries,' and establish their own Coromantee society in the interior. ${ }^{113}$

This incident truly gauged the loyalty of the Maroons to a new identity; the Kromanti identity, so instrumental to the development of the Maroons, had become subsumed under the Maroon identity

\footnotetext{
${ }^{110}$ Gottlieb,71.

${ }^{111}$ Kenneth Bilby, “'Two Sister Pikni': A Historical Tradition of Dual Ethnogenesis in Eastern Jamaica," Caribbean Quarterly 30 (1984): 13.

${ }_{112}$ Gottlieb, 73.

${ }^{113}$ Kopytoff, The Maroons of Jamaica, 181.
} 
with the signing of the treaty. This was the most dangerous kind of factionalism; factionalism along political lines posed not nearly so great a threat to Maroon identity as the revolt of some Maroons against both the terms of the 1739 treaty and against the mythology of Nanny and the founding of the Maroon ethnicity. Kojo dealt with this problem accordingly, and sent the four Maroon ringleaders for trial by the British government. "Two were sentenced to die and two to be transported," but the Governor showed clemency and sent the Maroons back to Kojo. ${ }^{114}$ Kojo hung the two sentenced to death and sent the other two to the Governor to be deported from the island. $^{115}$

So fundamental to the Maroon worldview is the Maroon/non-Maroon chasm that its maintenance has often provoked conflict. For example, as the British endeavored to negotiate a peace with the Leeward Maroons under the direction of Kojo prior to the signing of the 1739 treaty, "the most delicate question...was the status of Maroons who were relative newcomers to Maroon societies." dangerous proposition, one which could encourage other slaves to revolt, run away, and otherwise wreak havoc on the plantation system; to the Maroons, any and all Maroons, no matter how recently they had joined the communities, were the children of Nanny, and thus free. In negotiating with the Leeward Maroons, Governor Trelawny advocated for either the return of recently (those who had been in the woods for less than two to five years, and variously suggested by members of the Jamaican Assembly) fugitive slaves, or for their use "as slaves in the publick service."117 An interesting resolution was reached in the final draft of the treaty. The second clause reads:

That the said Captain Cudjoe, the rest of his Captains, Adherents and Men, shall be for ever hereafter in a perfect State of Freedom and Liberty, excepting those who have been taken by them, or fled to them within two years last past, if such are willing to return to their said Masters and Owners, with full Pardon and Indemnity from their said masters or Owners for what is past. Provided always, That if they are not willing to return, they shall remain in Subjection to Captain Cudjoe, and in Friendship with us, according to the Form and Tenor of this Treaty. ${ }^{118}$

\footnotetext{
${ }^{114}$ Kopytoff, The Maroons of Jamaica, 181.

${ }^{115}$ Kopytoff, The Maroons of Jamaica, 181.

${ }^{116}$ M. Campbell, 111.

${ }^{117}$ British C.O. 137/56, Trelawny to Guthrie, February 23, 1738.

${ }^{118}$ British C.O. 137/23, Trelawny to Board of Trade, March 30, 1739.
} 
with the signing of the treaty. This was the most dangerous kind of factionalism; factionalism along political lines posed not nearly so great a threat to Maroon identity as the revolt of some Maroons against both the terms of the 1739 treaty and against the mythology of Nanny and the founding of the Maroon ethnicity. Kojo dealt with this problem accordingly, and sent the four Maroon ringleaders for trial by the British government. "Two were sentenced to die and two to be transported," but the Governor showed clemency and sent the Maroons back to Kojo. ${ }^{114}$ Kojo hung the two sentenced to death and sent the other two to the Governor to be deported from the island. ${ }^{115}$

So fundamental to the Maroon worldview is the Maroon/non-Maroon chasm that its maintenance has often provoked conflict. For example, as the British endeavored to negotiate a peace with the Leeward Maroons under the direction of Kojo prior to the signing of the 1739 treaty, "the most delicate question...was the status of Maroons who were relative newcomers to Maroon societies."116 To the British, allowing for the freedom of recently escaped slaves was an enormously dangerous proposition, one which could encourage other slaves to revolt, run away, and otherwise wreak havoc on the plantation system; to the Maroons, any and all Maroons, no matter how recently they had joined the communities, were the children of Nanny, and thus free. In negotiating with the Leeward Maroons, Governor Trelawny advocated for either the return of recently (those who had been in the woods for less than two to five years, and variously suggested by members of the Jamaican Assembly) fugitive slaves, or for their use "as slaves in the publick service."117 An interesting resolution was reached in the final draft of the treaty. The second clause reads:

That the said Captain Cudjoe, the rest of his Captains, Adherents and Men, shall be for ever hereafter in a perfect State of Freedom and Liberty, excepting those who have been taken by them, or fled to them within two years last past, if such are willing to return to their said Masters and Owners, with full Pardon and Indemnity from their said masters or Owners for what is past. Provided always, That if they are not willing to return, they shall remain in Subjection to Captain Cudjoe, and in Friendship with us, according to the Form and Tenor of this Treaty. ${ }^{118}$

\footnotetext{
${ }^{114}$ Kopytoff, The Maroons of Jamaica, 181.

${ }^{115}$ Kopytoff, The Maroons of Jamaica, 181.

${ }^{116}$ M. Campbell, 111.

${ }^{117}$ British C.O. 137/56, Trelawny to Guthrie, February 23, 1738.

${ }^{118}$ British C.O. 137/23, Trelawny to Board of Trade, March 30, 1739.
} 
This clause notably records a tone of deference on the part of the British who, with all of the tactical and material advantages, could not defeat the Maroons. In essence, the latter half of the second clause, which permits the more recent fugitive slaves to remain with Kojo and the other Maroons without penalty, annuls the first half of the clause, wherein such recent fugitives were to be returned to their former masters if the former slaves so chose; as might be expected, there is no evidence of any Maroon choosing to return to the plantation. Here, the British accepted the agency of the Maroons to define Maroon identity. However, the British establish Kojo as a proxy master, in a manner similar to the Windward Treaty's deeding of land to Nanny as an individual. Once brought to the point of ceding military defeat by signing a treaty, the British attempted to shift tactics by forcing the Maroon societies into the mold of the emerging bourgeois-individualistically-oriented British plantocracy.

The Maroons so clearly saw themselves as distinct from the non-Maroon Blacks that they were willing to wage war to defend the honor they perceived in that distinction. As the children of Nanny, Maroons believed themselves to be separate from and superior to the children of Sekesu, who remained a slave out of trepidation. Before the Treaty of 1739, fugitive slaves continuously joined the Maroons; through the act of maroonage, and the subsequent oath of incorporation, these fugitives became children of Nanny. After the signing of the treaty, however, the barrier between Maroon and non-Maroon was no longer permeable. To the British, the 1739 treaties marked a need to shift from a paradigm of military conquest to tactics of aggressive cultural sabotage. The guerilla warfare tactics of the Maroons had proven too difficult and costly for the British to defeat; seeking to maintain colonial power, the British instead attempted a combined campaign of isolation and limitation in prohibiting the Maroon acceptance of new fugitives, and assimilation, in attempting, through law, to transform the African cultural sensibilities into acquisitive individualism. Once the British understood that the ferocity of Maroon combat would not brook a return to subjugation, they were forced to shift tactics to utilize a more divisive approach. The British understood that allowing the development of a unified race consciousness of Black Jamaicans would create an untenable situation for the minority British; in facilitating the fragmentation of identity by creating a rigid barrier between Maroon and non-Maroon through the clause of the Treaties of 1739 that forced the Maroons to return fugitive slaves, the British helped ensure the security of their position well into the twentieth century.

The perception of the tenuousness of their position is evident in the diaries of White Jamaicans of the eighteenth and nineteenth century, such as those of Thomas Thistlewood and Lady 
Nugent, which reveal an omnipresent fear of slave revolt. An anonymous Jamaican essay published in 1746 proclaimed "if some Stop not be put to it [the buying of Africans], or if better Discipline not be observed, the Island must be overrun, and ruined by its own Slaves."119 Monumentally outnumbered and perpetually paralyzed by fear for their lives and economic viability, the British used divisive tactics as the only viable means of maintaining their position. Evidence for the partial success of the British efforts was demonstrated by the ending of Tacky's Rebellion, the largest slave rebellion on the island, with a Maroon sharpshooter killing Tacky. This divide-and-conquer British policy neatly fit with the mythological constructs used by the Maroons to forge a cohesive identity of their own. The Maroons did not think in terms of racial consciousness or unity, but rather in terms of fealty to their own people, the Maroons. They were not thus betraying those whom they left behind. Whatever nefarious aims of the British may have been accomplished through this aspect of the treaties, the Maroons accomplished that which they had endeavored to do: establish an independent community, safe from, and outside of, the hegemonic order.

The Windward and Leeward Treaties of 1739 institutionalized Maroon identity. No longer "rebellious Negroes," the former fugitives now had rights and duties in the eyes of the British crown; more importantly, to the Maroons, they had rights and duties that were sworn upon by a sacred blood oath, sworn to the gods. The cohesion of the Maroons into a singular ethnic identity occurred within the period between 1690, and the revolt of the Kromantis in Clarendon, and 1739, or one or two generations. Though amazingly rapid, this identity would be a powerful force in Jamaican history. This distinct identity would ensure Maroon survival, and it would also create massive conflict with the interests of other Africans in Jamaica.

\section{THE RIFT BETWEEN THE CHILDREN OF NANNY AND THE CHILDREN OF SEKESU}

The feature of the treaties that has proven the most problematic to scholars and Maroons alike is the clause that altered the role of Maroons from allies of fugitive slave to the aggressive pursuers and captors of fugitive slaves and rebels. In the Leeward Treaty, this dictate is contained in the ninth clause, which reads:

\footnotetext{
${ }^{119}$ An Essay Concerning Slavery and the Danger Jamaica is Expos'd to From Too Great Number of Slaves...(London, 1746), 18.
} 
[t]hat if any Negroes shall hereafter run away from their Masters or Owners, and fall into Captain Cudjoe's Hands, they shall immediately be sent back to the Chief Magistrate of the next parish where they are taken; and those that bring them are to be satisfied for the Trouble, as the Legislature shall appoint. ${ }^{120}$

In the Windward Treaty, the language is even stronger. In this treaty, the fourth clause reads:

[t]hat the said Captain Quao and his People shall be ready on all Commands the Governor or the Commander in chief for the Time being shall send him, to suppress and destroy all other Party and Parties of rebellious Negroes, that now are or shall from Time to Time gather together or settle in any Part of this Island, and shall bring in such other Negroes as shall from Time to Time run away from their respective Owners, from the Date of these Articles. ${ }^{121}$

An attempt to interpret Maroon history through a narrative structure of rebellion and resistance demands that these clauses be seen as acts of betrayal on the part of the Maroons; this interpretation conflicts with the rebellion theorists' substantiated belief that the Maroons negotiated with the British as military equals, if not superiors. ${ }^{122}$ Other interpretations posit that the Maroons were overwhelmed by the superior diplomatic skill of the British, who employed the treaty as the most effective tool from the arsenal of empire. ${ }^{123}$ However, this clause cohered perfectly with the Maroon notion of self and liberty. Even if the children of Sekesu could, even months before the signing of the treaties in 1739, become the children of Nanny, the Maroons always observed a strict divide between the two; those bound by the Asante blood oath, the men and women of the Maroon communities, constituted a closed and secretive society. Acts perceived as hostile toward the slaves no more violated the code of Maroon ethics than violence against the British; Maroon identity was conceived along cultural, not racial, lines. Indeed, the Maroons constructed their own identity as the native children of the land of Jamaica's interior which they knew so well, and whose original inhabitants, the Arawak, had all been either killed or assimilated into Maroon society by the seventeenth century. ${ }^{124}$ If the Maroons constituted a unique, cohesive,

\footnotetext{
${ }^{120}$ British C.O. 137/23, Trelawny to Board of Trade, March 30, 1739.

${ }^{121}$ British C.O. 137/56, June 30, 1739.

${ }^{122}$ M. Campbell.

${ }^{123}$ Kopytoff, The Maroons of Jamaica.

124 Zips.
} 
exclusive, and indigenous group, then the acts of violence committed to comply with the return of fugitive slave clauses become comprehensible as the acts of a native population against a perceived settler population. As Mahmood Mamdani elucidated in a radically different context: "[t]he very political character of native violence made it difficult to think of it as an impulse to genocide. Because it was derivative of settler violence...[it] appeared less of an outright aggression and more a self-defense in the face of continuing aggression." ${ }^{\prime 25}$ While the comparison may seem extreme, the consequences of returning fugitive slaves and quashing slave revolts were dire to the lives of those still enslaved. The Maroons, however, were simply acting in a manner conducive to the maintenance of their positive liberty and autonomy by treating with the British settler population, from whom they could gain recognition of the positive liberty, in addition to the important negative liberties secured in the treaties.

The nature of the Maroon's struggle against the British, which ended in 1739, and the later rebellions was widely divergent. Much of this difference originated in the economic and social changes which occurred in Britain and its colonies between the early and late eighteenth century. After the Glorious Revolution of 1688, Britain and its colonies slowly embarked on a transformation from late seigneurialism to capitalism; such an alteration represented an idealistic shift for the British from an underlying belief in reciprocal obligation to one of bourgeois individualism. Rebels and runaways who later became Maroons sought to create a separate society outside of the hegemonic order. Because of this, it was entirely logical to sign a treaty with the British that would entail obligations to return runaways and quell rebellions, as long as the autonomy of the Maroons was recognized. Later rebels, like L'Ouverture in Haiti, appropriated the ideology of capitalism to demand "not secession from the dominant society [as did the Maroons] but... [rather to] join...it on equal terms."126 Maroons had sought to escape from the slave polity and form their own society where their own cultural norms, variously construed as "African" or "Kromanti," but more accurately described as a unique syncretic creation within which constituent elements from Akan and other African societies prevailed. Seventeenth-century and eighteenth-century Maroons did not believe in the universal rights of man, nor in the ultimate ascendance of the individual; later rebels

\footnotetext{
${ }^{125}$ Mahmood Mamdani, When Victims Become Killers: Colonialism, Nativism, and the Genocide in Rwanda (Princeton: Princeton University Press, 2001), 10.

${ }^{126}$ Eugene D. Genovese, From Rebellion to Revolution: Afro-American Slave Revolts in the Making of the Modern World (Baton Rouge, LA: Louisiana State University Press, 1981), xvii-xx.
} 
did. This paradigm conflict generated enormous contention between the Maroons and nonMaroons in Jamaica.

One of the provisions of the treaty of 1739 was that the Maroons agreed to suppress and destroy all other Party and Parties of rebellious Negroes, that now are or shall from Time to Time gather together or settle in any Part of this Island, and shall bring in such Negroes as shall from Time to Time run away from their respective Owners, from the Date of these Articles. ${ }^{127}$

The Maroons faithfully adhered to this component of the treaty, and, through these actions, created great enmity between themselves and the slaves. Indeed, the slaves resented the perceived elitism of the Maroons, who, through the treaties of 1739 and the land grant to Nanny, had been given a status elevated and exalted beyond their own. The mutual hatred was exacerbated in 1760, when the Scot's Hall Maroons helped the British defeat Tacky's Rebellion, “a revolt of at least 400 slaves, which triggered other revolts, one of which engaged about a thousand." ${ }^{\text {"28 }}$ Tacky was a Kromanti; thus, by 1760 , the Maroon identification as Maroon, rather than Kromanti, was firmly entrenched. ${ }^{129}$ To the non-Maroons, the Maroons were agents of repression, and haughty flaunters of privilege; to the Maroons, the non-Maroons represented the cowardly children of Sekesu, who "chose to avoid bloodshed by remaining a slave."

The Maroons gained renown for their effectiveness in quashing slave rebellions and catching runaways. In addition to Tacky's rebellion, the Maroons killed Three-Finger Jack, who led a group of sixty runaways in raiding plantations in St. David's parish; when the Maroons came upon ThreeFinger Jack and surprised him, they killed him "cut off his head and arm, and carried them to Kingston for a $£_{100}$ reward."131 Not only did Three-Finger Jack's defeat anger his followers, and all those still enslaved on the plantations who derived much more hope for their own freedom from the actions of men such as Three-Finger Jack than they did from the apparent restorationist selfinterest of the Maroons, but the manner in which the Maroons dealt with Three-Finger Jack's body served to intensify fear of the Maroons.

\footnotetext{
${ }^{127}$ British C.O. 137/56, June 30, 1739.

${ }^{128}$ Genovese, 1-50.

${ }^{129}$ Kopytoff, The Maroons of Jamaica, 235.

${ }^{130}$ Gottlieb, 71.

${ }^{131}$ Kopytoff, The Maroons of Jamaica, 237-8.
} 
In 1795, a community of runaways known as the Congo Settlement, which had been raiding plantations and living autonomously for twenty years, was discovered by a group of Maroons. The settlement "was dispersed, some of the negroes returning to the estates to which they formerly belonged, and others surrendering with the Maroons at the termination of the [Second Maroon] war." ${ }^{\prime 132}$ In 1824, the Maroons destroyed another independent runaway settlement in the Cockpits. ${ }^{133}$ Regular parties of Maroons sought and captured runaways, for whose return they were paid. This source of income was vital to the Maroons, who never established an economy autonomous of the rest of Jamaica, and who were prevented by treaty from growing the most profitable cash crop, sugar. $^{134}$ In the years prior to the treaty, the military successes of the Maroons inspired many plantation slaves to rebel or run away; in the years following the treaty, virtually every attempt to rebel or flee was thwarted by the Maroons. The Maroons thus became feared and despised by the vast majority of non-Maroons.

Even after Emancipation, and the disappearance of the crucial income from the capture of runaway slaves, the Maroons continued to honor the terms of the treaty. In 1865, Paul Bogle led nearly 500 Blacks on a march to Morant Bay to protest injustices, such as the disenfranchisement of the Blacks and the plight of the poor. Bogle believed that he had the support of the Windward Maroons, and told the others involved in the protest that "the Maroons is our back." 135 The Jamaican government called the Maroons to assist in crushing the "rebellion," and, ultimately, the Windward Maroons captured Paul Bogle, who was later hung, and aided the colonial government in executing 438 people who participated. ${ }^{136}$ Jamaicans still cite the "betrayal of Paul Bogle" as the major reason for dislike of and prejudice towards Maroons.

Long before the Morant Bay incident, the hatred and resentment between the Maroons and non-Maroons exploded in 1795. In July of that year, two Trelawny Town Maroons were convicted "by the evidence of two white people, of killing tame hogs."137 The British chose to punish the convicted Maroons by having them flogged by a slave. The embittered slaves were thrilled at the opportunity to exact revenge upon the Maroons, and, as the Maroons "went through the town and plantation they were laughed at, hissed, and hooted by the slaves."138 To the Maroons, this

\footnotetext{
132 Dallas, 101.

${ }^{133}$ Kopytoff, The Maroons of Jamaica, 238.

134 British C.O. 137/23, Trelawny to Board of Trade, March 30, 1739.

${ }^{135}$ M. Campbell, 249.

136 Jamaican Ministry of Youth, Education, and Culture.

137 Dallas, 145.

138 Dallas, 145.
} 
represented the vilest and most unacceptable degradation; to be flogged was associated with the inferior status of a slave. For a Maroon, particularly of the generation or two following those who had fought in the First Maroon Wars and secured independence in the Treaties of 1739, who would have been raised on stories of the glory of freedom and the superiority of the Maroons, to be flogged by a slave was an unthinkable affront to Maroon identity. This conflict sparked the Second Maroon War, which ended only with the exile of the rebelling Maroons of Trelawny to Nova Scotia.

The lessening of the sharp divide between Maroon and non-Maroon in recent times reflects as much the acceptance of the ideology of bourgeois individualism by the Maroons as it does the greater contact between the groups and the infusion of Pan-Africanist and Rastafarian ideas. Indeed, not only do modern Maroons deny ever having owned slaves, but they also deny that Maroons ever returned fugitive slaves or participated in quashing slave rebellions. ${ }^{139}$ Originally, the Maroons entered an agreement with the British that was based on a shared understanding of reciprocal obligations; this belief was as much a part of most African traditions, including Akan, as it was integral to feudal Europe. As ideas held by both slaves and masters changed to favor a belief in individual rights and equality as a function of participation in the dominant system, the Maroons became an increasingly stigmatized relic of the past, reviled by the non-Maroons.

\section{SLAVERY IN AFRICA AND AMONGST THE MAROONS}

In addition to frequent and passionate accusations of betrayal, modern Jamaicans often deride the Maroons for having been a slaveholding elite. Slavery as practiced by the Maroons has been neglected as a topic of study, and direct data, beyond the incomplete, fragmentary, and inconsistent census records kept by the British superintendent of Maroon communities and a few cursory mentions in private correspondences, are unavailable. By applying the limited available information to analytic frameworks developed to understand slavery in Africa and the New World, however, some extrapolation about the practice of slavery by the Maroons is possible. Fortunately, data concerning the practice of plantation slavery in Jamaica abound. In comparing these two institutions, it is useful to adopt the approach of Ira Berlin in Generations of Captivity: A History of African-American Slaves to distinguish between societies with slaves and slave societies. ${ }^{140}$ Societies with slaves were characterized by small slaveholdings and a permeable and fluid line between slavery

\footnotetext{
${ }^{139}$ Reid.

${ }^{140}$ Ira Berlin, Generations of Captivity: A History of African-American Slaves (Cambridge, MA: Harvard University Press, 2003), 8-9.
} 
and freedom. For example, enslaved Africans in seventeenth-century New Netherlands often lived and worked alongside Europeans and Native Americans of all ethnicities, and were frequently utilized as interpreters amongst Europeans of different nationalities; the occupations and lives of free people and enslaved people in this setting, and the relative degree of agency possessed by each, were not so distinct. ${ }^{141}$ This relative mutability did not necessarily translate into more humane treatment of slaves. Sometimes, the extraneousness of slaves in societies with slaves to market value rendered them more vulnerable to brutality. By contrast, slave societies positioned "slavery at the center of economic production, and the master-slave relationship provided the model for all social relations." 142 In societies with slaves, slave owners did not comprise the entirety of the elite as they did in slave societies. Justification for slavery in slave societies was predicated upon an ostensible rule of nature or of a god or gods. ${ }^{143}$ Slavery as practiced by the British in Jamaica was certainly a typical example of slave society. Because of an absence of data, it is difficult to make such a strong assertion about slavery as practiced by the Maroons. However, by analyzing slavery as practiced in Kongo, Asante, and Igbo societies, and by examining the transformations in culture that occurred between sale in Africa and maroonage in Jamaica, it is possible to assert that Maroon society was a society with slaves, in which the primary role of slavery was to reinforce the ethnic uniqueness of the Maroons, and the kinship system, and not the master-slave relationship, was the primary social model.

Slave ownership was, indeed, a crucial facet of the West African economy. Slavery was such an integral element of West African culture because "slaves were the only form of private, revenueproducing property recognized in African law."144 Under European law, private land ownership, and the revenue produced thereof, was privileged. Nobility was contingent upon the ability to will land, and, most crucially, the wealth accrued through ownership of the land and sale of its produce, to offspring. By contrast, African land was owned corporately. Instead of taxing land, as was done in Europe, many centralized African polities, such as the Kingdom of the Kongo, accumulated revenue by taxing slave owners based on the numbers of slaves owned. ${ }^{145}$ While Europeans controlled land, wealthy Africans controlled labor. Wealthy and entrepreneuing Africans invested in slaves as a dependable and secure source of reproducing wealth, and African states utilized slaves both to

\footnotetext{
${ }^{141}$ Berlin, Generations of Captivity, 32.

${ }^{142}$ Berlin, Generations of Captivity, 8-9.

${ }^{143}$ Berlin, Generations of Captivity, 10.

${ }^{144}$ John Thornton, Africa and Africans in the Making of the Atlantic World, 1400-1800 (New York: Cambridge University Press, 1998), 74.

${ }^{145}$ Thornton, 77.
} 
increase revenue, through agricultural production and public works, and also in administrative and military capacities. ${ }^{146}$ These practices pervaded western, west central and central Africa, in all of the regions from which people involved in the trans-Atlantic trade were taken. To the survivors of the Middle Passage, slavery itself was certainly not a novelty.

Because of the obvious cruelty and devastation wrought by the trans-Atlantic slave trade, many post-colonial authors have tended to artificially polarize pre-colonial African society into a White-as-evil, Black-as-victimized duality. Clearly, wealthy Africans controlled the terms of the trans-Atlantic trade as readily as they controlled the internal commerce in slaves. For example, Benin began to restrict the trans-Atlantic slave commerce as early as 1520, and had effectively stopped participating in this traffic by 1550, though, under later rulers, Benin re-engaged in the trans-Atlantic trade. ${ }^{147}$ In Africa and Africans in the Making of the Atlantic World, 1400-1800, John Thornton proposes that local labor needs largely dictated what restrictions were placed on transAtlantic trade, and to what extent given political entities participated in this commerce. ${ }^{148}$ Contemporary Africans did not appear to view themselves as victims of European caprice, military strength, or economic or political coercion; rather, to the wealthy Africans who benefited from the slave trade, it was simply another market within which to trade a dependable commodity. Consequently, those Africans who survived the Middle Passage, while almost certainly not often of the class who directly benefited from the slave trade, originated in a social paradigm in which slave ownership was the single most important marker of status.

The Akan states of the Gold Coast have long been asserted to be the societies from which the majority of the Jamaican Maroon population, including the Maroon leaders Kojo and Nanny, derived. Thus, it is instructive to examine slavery as practiced specifically within Asante. Formation of the Akan states (notably Asante and Fante) was catalyzed largely "by the European mercantile presence along the Gold Coast [in the fifteenth and sixteenth centuries]...[g]old was exchanged for slaves and otherwise unfree labour, much of it imported into the Gold Coast by Europeans from other parts of western Africa."149 The economic process of gold production and export from the Akan states both created and reinforced slavery: mining heavily utilized slave labor, and slaves used in mining required a surplus of food that could be produced by slaves. Indeed, as Claude Meillassoux argues, "a gross surplus-product can be created only through the limitation of

\footnotetext{
${ }^{146}$ Thornton, 89.

${ }_{147}^{147}$ A.F.C. Ryder, Benin and the Europeans (New York: Humanities Press, 1969), 56-90.

${ }^{148}$ Thornton, 110-1.

${ }^{149}$ McCaskie, 25.
} 
demographic growth and the social allocation of children," which, in a society like Asante, where matrilineal kinship controls land access, is possible only through slavery. ${ }^{150}$

In Asante, "full citizenship rights...were exclusively vested in and defined by membership of an abusua [matrilineal clan] and, more broadly, an abusua kesee [territorially dispersed matriclan]."151 Land was relatively plentiful in Asante, as elsewhere in Africa. Due to this abundance of land, labor was in constant demand, and free people, who had the land of their own matrilineage to work, could not be prevailed upon to labor on another's land for wages. ${ }^{152}$ For example, kola nuts, long valuable in the trade within Africa, and also profitable for trade with Europeans, come from matrilineallyowned trees; "hence kola nuts were virtually a free good for lineage members, [and] additionally labor could increase production considerably." 153

Within this context of abundant land, to which all members of a matrilineage had usage rights, modes of increasing production through slavery were gender-specific. In matrilineal societies, a man's descendents are his sister's children. A male outsider in an Akan community would have no socially recognized children; thus, the male condition of slavery in Akan society is bound to his "social incapacity...to reproduce socially -- that is, the slave’s juridical inability to become kin." 154 A male slave had no socially recognized offspring, and, thus, perpetually produced surplus goods for a lineage not obliged to produce for him in his old age. Women, however, formed the bulk of the slave population in Africa, while men were the predominant export to the Americas. ${ }^{155}$ Women were in high demand as slaves, not only for their agricultural labor, since crop growing is women's labor in Akan societies, but also for their reproductive capacity. Children of a free man and a slave woman would become part of the father's lineage through the establishment of a slave branch of the abusua; without brothers to advocate for the slave woman's children, they became a means by which a free male could socially reproduce himself. ${ }^{156}$ So prevalent was this practice that, eventually, the

\footnotetext{
${ }^{150}$ Claude Meillassoux, The Anthropology of Slavery: The Womb of Iron and Gold, trans. by Alide Dasnois, (London: The University of Chicago Press, 1991), 35.

${ }^{151}$ McCaskie, 88.

${ }^{152}$ Anthony G. Hopkins, An Economic History of West Africa, (New York: Columbia University Press, 1973), 24.

${ }^{153}$ A. Norman Klein, "The Two Asantes: Competing Interpretations of 'Slavery' in Akan-Asante Culture and Society," in The Ideology of Slavery in Africa, ed. Paul E. Lovejoy (Beverly Hills, CA: Sage Publications, 1981), 153.

${ }^{154}$ Meillassoux, 35.

${ }^{155}$ Claire C. Robertson and Martin A. Klein, "Women's Importance in African Slave Systems," in Women and Slavery in Africa, eds. Claire C. Robertson and Martin A. Klein (Madison, WI: The University of Wisconsin Press, 1983), 4-5.

${ }^{156}$ Susan Herlin Broadhead, "Slave Wives, Free Sisters: Bakongo Women and Slavery c. 1700-1850," in Women and Slavery in Africa, eds. Claire C. Robertson and Martin A. Klein (Madison, WI: The University of Wisconsin Press, 1983), 170-171.
} 
Asantehene, or ruler of the Asante, made it illegal to ask a person about his or her antecedents. ${ }^{157}$ Thus, male slaves were valued only for production, while female slaves had the added value of reproduction. Slaves, who were usually war captives, were perpetual foreigners, or odonko; children of slaves, however, could be assimilated into the kinship structure of the Asante. ${ }^{158}$

This Asante context for slavery has important implications for understanding Maroon society. First, the pervasiveness of slavery in the societies from which the Maroons came, and the degree to which it appeared to be a total institution, render the reality of maroonage more remarkable. Not only did Maroons escape from, and successfully rebel against, the racialized chattel slavery of eighteenth-century Jamaica, but they also escaped from the confines of the social structure from which they had come. In Asante, slaves were "ethnically diverse, far from home, stigmatized by a halting or inflected Twi, and often distinguished by cicatrization," conditions essentially identical to those faced by slaves in Jamaica. ${ }^{159}$ Asante distinguished between odonko, or foreign war captive slaves, and slaves from other Akan polities. ${ }^{160}$ By controlling the means by which a person could be jurally incorporated into Asante while extending the hope for such an incorporation, the Asante state effectively precluded the slave rebellion it so feared; "the Asante themselves claimed descent from one of seven matriclans, and technically only people who could trace their descent through the female line to one of these founding clans were full citizens." "161 It was only through eventual integration into the matrilineage that Asante slaves could assimilate; escaping the condition of slavery without association with a matrilineage seemed conceptually impossible. Speaking in 1841, the Asantehene Kwaku Dua Panin said that "the small tribes in the interior fight with each other, take prisoners and sell them for slaves...I allow my people to buy and sell them as they please: they are of no use for any thing else but slaves; they are stupid, and little better than beasts."162 Furthermore, the Asantehene could physically disperse slaves to prevent collective organization, and, at the slave owner's request, a slave could be reclassified as destined for ritual sacrifice. ${ }^{163}$ In Jamaica, the British were such a minority that such dispersal and isolation was impossible; according to British Colonial Office statistics, in 1730, Whites comprised approximately $9.8 \%$ of Jamaica's

\footnotetext{
${ }^{157}$ Robertson and Klein, 7.

${ }^{158}$ McCaskie, 97.

${ }^{159}$ McCaskie, 96-97.

${ }^{160}$ Klein, 151.

${ }^{161}$ Klein, 151.

${ }^{162}$ McCaskie, 96.

${ }^{163}$ McCaskie, 97-98.
} 
population. ${ }^{164}$ While many argue that maroonage is a natural by-product of the fundamental cruelty of slavery, not all of the enslaved became Maroons, and not all societies with slaves, or slave societies, produced corresponding Maroon communities. ${ }^{165}$

The Igbo of Nigeria are another ethnic group from whom there is evidence that elements of the Maroons derived. Ibgoland differed from Asante in that the fundamental social unit was the patrilineage, and the village organized around a corporate group of patrilineages, rather than matrilineages, as with the Asante. ${ }^{166}$ Social standing in Igboland was determined by the number of people the head of a patriclan could control, including slaves, wives and children; this, combined with the agrarian nature of the Igbo economy which rewarded with wealth those who controlled the most labor, provided the initial impetus for slavery in Igboland. Slavery was "never the basis of the social system" in Igboland, and only a small number of Igbo owned slaves; Igbo were more often taken as slaves by neighboring polities, to whom Igboland was considered an inland hinterland. ${ }^{167}$

Generally, slaves of the Igbo performed the same economic tasks as free members of the household, such as fishing and farming, and, thus, were often in contact with free people. The only exception was amongst the northern Igbo communities, who were most prone to slave raids; in these communities, satellite villages of slaves were established as a defensive measure. In Igboland, there was a hierarchy of slave status. Bought slaves had less prestige than those born into slavery, and slaves that had been associated with families for longer had more status than recently acquired slaves did. Young girls, who commanded the highest prices in the slave markets, often married into the family to whom they were enslaved and thus secured liberty. Slaves of the Igbo were allowed one day out of the four day week to work for themselves; male slaves who parlayed their crops into cattle wealth could often advance in status, and their children, perhaps, could be adopted into a lineage by virtue of this acquired wealth. ${ }^{168}$

Clearly, slavery as practiced in the Akan states, particularly amongst the Asante, slavery as practiced in Igboland and Kongo, and slavery as practiced by Europeans evolved separately, though after the fifteenth century, these distinct institutions influenced each other. As previously mentioned, women were in higher demand and commanded higher prices in African slave markets, a reality that contributed to the overwhelming sex imbalance of African slave populations in the

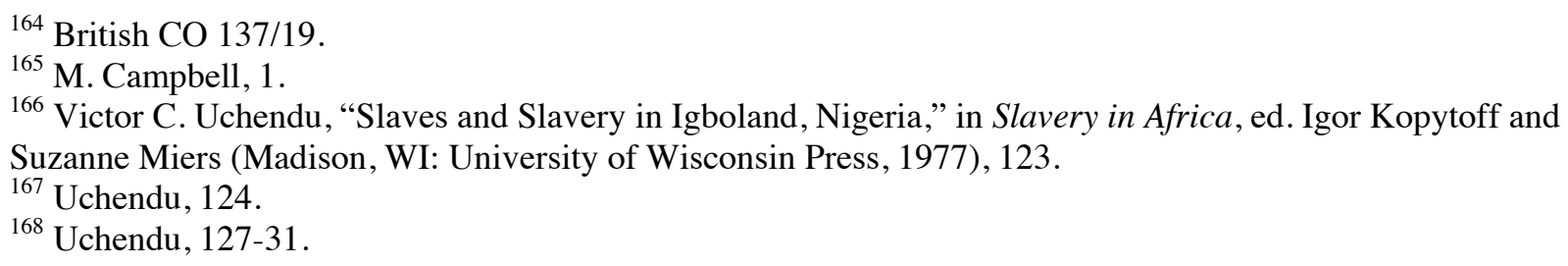


New World. Between 1676 and1700, 56.5\% of slaves that disembarked in Jamaica were male; between 1701 and 1725, when Asante had a greater abundance of war captives, 72\% of slaves disembarking in Jamaica were male. ${ }^{169}$ Western scholars have often labeled African slavery as "benign," both because it did not resemble plantation slavery in the Americas, and because colonial administrators in Africa were wary of contending with "the political problems of suppressing it."170 Edward Long, in his 1774 History of Jamaica, claims that, in Africa, "the slaves of family are considered as no mean part of it; scarce any of them are sold, except for great crimes...they meet with no interruption, provided they acknowledge their subservience from time to time, and pay a tribute." ${ }^{171}$ Though it is easy to understand the stake colonial administrators and later writers would have in depicting African slavery as more benign, such claims seem ideologically out of place in the midst of Long's lengthy arguments justifying the European trade, which he characterizes as entirely different. Perhaps it is not possible to assess relative cruelty accurately, but it is possible to recognize that African slavery differed from American plantation slavery, both in derivation and in practice, and creating comparisons that do not ignore the glaringly different environmental, demographic, and social conditions in Africa and the New World are difficult. However, in the period between 1739, when the Maroons were formally recognized as a free and independent people by treaty with the British government, and 1834, when the British abolished slavery in all of its lands and colonies, the island of Jamaica was home to two very different socities, one a slave society and the other a society with slaves.

That the British-controlled slavery in Jamaica constituted a slave society is apparent from every examination of its structure and practice. Jamaica was "the largest producer of tropical goods in the British West Indies, accounting for 54 percent of tropical imports into Britain and approximately 13 percent of total imports into Britain," and "Jamaica's wealth was based on sugar and rum trade." 172 Cultivation of sugar and production of rum was conducted entirely by slaves; "between 1655 and 1808, 915,204 Africans landed in Jamaica. Of these, just over three-quarters were retained in the island." ${ }^{\prime 73}$ Between 1676 and 1725, the years most relevant to the First Maroon

\footnotetext{
${ }^{169}$ Eltis et al., Query and analysis of slaves disembarking in Jamaica between 1676-1700 and 1701-1725.

${ }^{170}$ Igor Kopytoff and Suzanne Miers, “African 'Slavery' as an Institution of Marginality,” in Slavery in Africa: Historical and Anthropological Perspectives, eds. Igor Kopytoff and Suzanne Miers (Madison, WI: The University of Wisconsin Press, 1977), 6.

${ }^{171}$ Long, 384-5.

172 Trevor Burnard and Kenneth Morgan, "The Dynamics of the Slave Market and Slave Purchasing in Jamaica, 1655-1788," William and Mary Quarterly, $3^{\text {rd }}$ ser., 58 (2001): 205-7.

${ }^{173}$ Burnard, Mastery, Tyranny, and Desire, 15.
} 
War, 181,114 slaves disembarked in Jamaica. ${ }^{174}$ Manumission was incredibly rare; Maroons constituted the only notable population of free Blacks on the island. ${ }^{175}$ The system of plantation slavery, as practiced by the British in Jamaica, relied upon continued importation of new slaves to fuel the sugar trade; without such slaves, the tiny minority of British on the island would have been economically insolvent. A slave-run sugar economy, however, allowed the British planters in Jamaica to form a highly moneyed elite. By 1774, "the average white in Jamaica was 36.6 times as wealthy as the average white in the thirteen colonies, 52.3 times as wealthy as the average white in England and Wales, and 57.6 times as wealthy as the average white in New England."176 Slavery and slave production were the sole basis for British power and money in eighteenth-century Jamaica.

In such a slave society, the British required an elaborate system of justification of slavery as natural. Some of this justification was grounded in Hamitic notions concerning the appropriate place in the order of the world and the relative inhumanity of Africans generally. Writing in 1774, Edward Long typified a Jamaican view towards enslaved Africans. Long argues that there is a surplus population of Africans who, if not sold into trans-Atlantic slavery, would be killed and eaten in Africa. ${ }^{177}$ Long attributes African reticence to be slaves to the Europeans to their belief "that they are bought in order to be fattened, roasted, and eaten," and that, upon learning otherwise, many wept for joy. ${ }^{178}$ Long also reports that Jamaican slaves with whom he spoke indicated that they preferred being enslaved in Jamaica than living free in Africa because they enjoyed a higher standard of material comforts. ${ }^{179}$ These justifications ring hollowly today, but, to the average eighteenthcentury British citizen, these statements were convincing.

The situation of slavery as practiced by the Maroons in Jamaica was much more nuanced than the well-documented British plantation system, and its history is obfuscated by a lack of evidence. As previously discussed, present day Maroons, pressured by Pan-African and Rastafarian political and social considerations and influenced by feedback from written sources, customarily deny that the Maroons had slaves. Documentary evidence, however, contradicts the assertions of these modern day Maroons. Governor Paul Sligo, who ruled Jamaica during Emancipation in 1834, was charged with the laborious process of registering claims of Jamaican slaveholders, who were

\footnotetext{
${ }^{174}$ Eltis et al., Query and analysis of slaves disembarking in Jamaica between 1676-1700 and 1701-1725.

${ }^{175}$ Jerome S. Handler and John T. Pohlmann, "Slave Manumissions and Freedmen in Seventeenth-Century Barbados," The William and Mary Quarterly, 41 (1984): 390.

${ }^{176}$ Burnard, Mastery, Tyranny, and Desire, 15.

${ }^{177}$ Long, 386-7.

${ }^{178}$ Long, 397.

${ }^{179}$ Long, 400.
} 
compensated for "loss of human property" by the British government. Writing to a friend on 3 November 1834, Sligo remarks:

The Maroons are holders of many slaves and have never registered them, but regular returns of their numbers, names, age and sex have been sent in as a matter of course each session to the Assembly; the Board has directed the Directors to make a report to return of these Individuals detailing the particular circumstances of the case, in order that the matter may be considered by the contract Board at home. ${ }^{180}$

Remarkably, at least three Maroons were clearly documented as having received compensation from the government of Great Britain for the loss of human property after Emancipation. James Rowe of Accompong registered a claim for six slaves, and was paid $f_{6} 651 .^{181}$ Catherine Dacree of Accompong was compensated $£, 513$ for two slaves, ${ }^{182}$ and Kate McLeary of Maroon Town was paid £163 for four slaves. ${ }^{183}$ Other claims appear to have originated from Maroons, but a more extensive examination of the registers is needed to confirm this. In these cases, the Maroon identity of the individuals listed is predicated upon their place of residence being listed as one of the Maroon villages; there is a small, but significant, possibility that those listed were merely non-Maroons living in Maroon villages.

The British, sensing a danger to the Great Chain of Being, passed a law in 1744 outlawing Maroon ownership of slaves. ${ }^{184}$ The law, entitled the "Act for the Better Order and Government of the Maroon towns," mandated "forfeiture of any slave bought by the Maroons and a stiff fine for any merchants selling slaves to them, as well as anyone assisting them in such a transaction."185 There is no record of the law being effectively enforced, and it continued to be re-enacted regularly until Emancipation. It is difficult to conjure a reason why such a regular discussion would occur in the Assembly of Jamaica if the Maroons did not have slaves.

Indeed, when Colonel Foster, leader of Accompong, died in 1820, he manumitted all five or six of his slaves in his will. Later, a non-Maroon "woman of color" disputed the will, and the British superintendent of Accompong commented that the slaves may have been fraudulently owned.

\footnotetext{
${ }^{180}$ Governor Paul Sligo to Rt. Honorable Rice, 3 November 1834, Letters of Governor Sligo, National Library of Jamaica, Kingston, Jamaica.

${ }^{181}$ Claims for Compensation Filed With the Assistant Commissioners for Jamaica, National Library of Jamaica, Kingston, Jamaica, $31^{\text {st }}$ sheet.

182 Claims for Compensation Filed With the Assistant Commissioners for Jamaica, $30^{\text {th }}$ sheet.

${ }^{183}$ Claims for Compensation Filed With the Assistant Commissioners for Jamaica, $17^{\text {th }}$ sheet.

${ }^{184}$ Kopytoff, The Maroons of Jamaica, 172.

${ }^{185}$ Kopytoff, The Maroons of Jamaica, 172.
} 
Another will from a Moore Town Maroon deeds two of his slaves to free Blacks in Port Antonio. Other records exist of Maroons hiring their slaves to work elsewhere and of Maroons and British buying and selling slaves from each other. ${ }^{186}$

The most detailed documentary source establishing the practice of slavery amongst the Jamaican Maroons was the census taken each year by the White superintendents of each Maroon town. In the same treaty by which the Maroons gained their legally recognized independence, the British established the right to have a superintendent residing in each Maroon community. The major responsibility of the superintendent was to submit a census each year. Despite the relatively low rigor of this job, the census are often incomplete and inconsistent, and, further, not regularly entered into the record of the Assembly of Jamaica. Some of the inconsistencies in the census data may be due to the incomplete records available in Jamaica; other difficulties may derive from the fact that it was illegal for Maroons to hold slaves, so several superintendents reported that Maroons concealed their slaves. ${ }^{187}$ Data for Accompong, Moore Town, Charles Town, and Scott's Hall appear only in the Journals of the Assembly of Jamaica for the years 1773, 1798-9, 1801-3, and 1809-21. ${ }^{188}$ Data on the Maroon populations are beset with such problems as aggregation of the women and girls in the Accompong census for 1817-1819 and the aggregation of men and women in Charles Town in 1815. Accounting for the slave populations of the Maroon communities was even more sporadic. Only in 1803, 1809, and 1817-1821 are slaves numbered in the Accompong and Charles Town census; Scott's Hall has slaves enumerated for 1798 in addition to 1803, 1809, and 1817-1821; Moore Town slaves are counted only in 1798, 1803, 1809, and $1819 .^{189}$ In no record are slaves differentiated by gender or age. Table 1 and Chart 1 show the percentage of slaves in the Maroon communities for years when the data is available. ${ }^{190}$

Table 1

Percentage of Resident Populations of Maroon Communities Enumerated as Slaves 1798
1803 1809 $4.03 \%$ $8.71 \%$ $6.27 \% \quad 6.96 \%$ 1817 1818 1819 1820 1821

Accompong $3.88 \%$ $4.43 \%$ $4.43 \%$ $3.63 \%$ $3.88 \%$

Charles Town $13.72 \%$ $15.00 \%$

$11.78 \%$

$12.06 \%$

$11.56 \%$

\footnotetext{
${ }^{186}$ Kopytoff, The Maroons of Jamaica, 173.

${ }^{187}$ Kopytoff, The Maroons of Jamaica, 174.

${ }^{188}$ Journals of the Assembly of Jamaica, 1773-1821.

${ }^{189}$ Journals of the Assembly of Jamaica, 1773-1821.

${ }^{190}$ Journals of the Assembly of Jamaica, 1773-1821.
} 

Moore Town 8.59\%
$8.82 \% \quad 9.46 \%$
$10.35 \%$
Scott's Hall
$6.00 \%$
$3.77 \%$
$4.35 \%$
$35.96 \%$
$40.91 \%$
$39.45 \%$
$38.53 \%$
$39.64 \%$

Chart 1

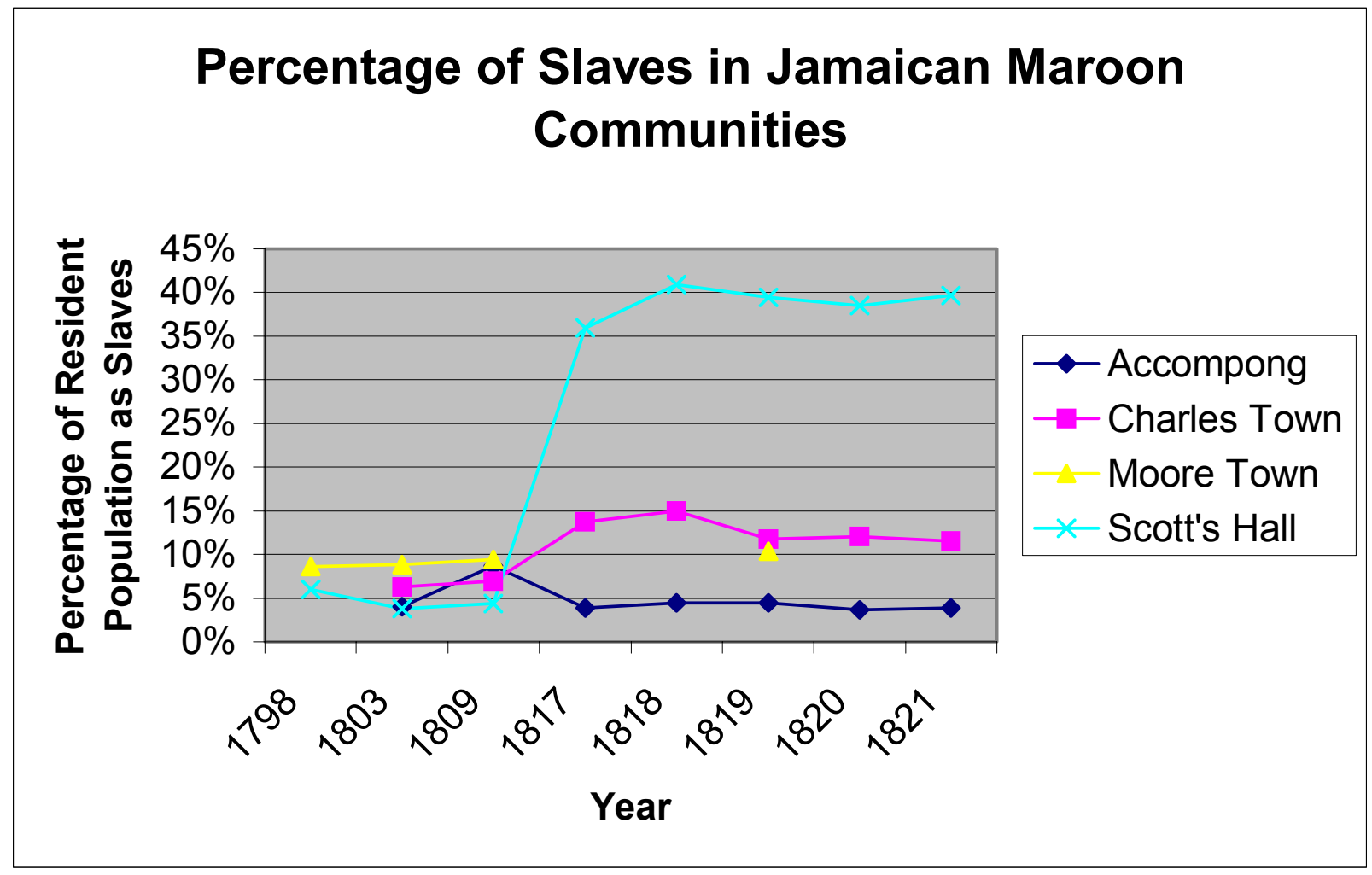

Though the data are inconsistently present, some trends emerge from these numbers. First, the smaller communities of Scott's Hall and Charles Town have a much larger percentage of slaves than do the larger communities of Accompong and Moore Town. Slave populations appear to have peaked for all communities save Accompong between 1817 and 1819. Though slave populations in Scott's Hall reached $40 \%$ of the total population, at no point did any community rival the percentage of slaves to free people in the larger polity of Jamaica, where roughly $90 \%$ of the population was enslaved. $^{191}$

It is difficult to ascertain the role of these variable slave populations in the economies of the Maroon communities. In pre-emancipation Jamaica, Maroons "combined subsistence agriculture with hunting, especially for wild hogs. There was a pronounced sexual division of labour; men were involved in hunting and military-type expeditions whilst women assumed responsibility for

${ }^{191}$ British CO 137/19. 
agriculture." ${ }^{192}$ The gender ratios are relatively stable across Maroon communities, so it is difficult to explain the much higher prevalence of slavery in the smaller communities in terms of a lack of available free women, or the need for a greater pool of agricultural laborers. ${ }^{193}$ It appears unlikely that the slaves of the Maroons were central to the economy. Furthermore, it is difficult to posit the existence of a slave-owning elite class amongst the Maroons. It is interesting to note that James Rowe, the Accompong Maroon compensated for six slaves, shares a surname with many Accompong colonels; in the absence of a greater amount of information, however, this is merely speculative conjecture about the possibility of a slave owning Rowe elite. While slaves were likely economically marginal to Maroon economies, they may have been central to Maroon ethnogenesis. While the core of Maroon communities was formed of Akan peoples, there was a wide range of other ethnicities within Maroon communities. Because of the potential conflicts arising from this diversity, Kojo mandated that Maroons speak English only; Kojo was likely well aware of the degree to which the Akan Asantehene depended on factionalism to quell any nascent slave revolts. The Akan people in Jamaica appear to have lost the matrilineal nature of their kinship system; while other Maroon groups such as the Saramaka of Suriname maintained matrilineality, the Jamaican Maroons appear neither matrilineal nor patrilineal. ${ }^{194}$ However, Jamaican Maroons clearly asserted their distinctiveness from non-Maroons, and owning slaves may have been one means by which the Maroons maintained this separation.

Former Accompong Colonel Harris Cawley commented that Maroons do not celebrate Emancipation Day, as do the rest of Jamaicans, because Maroons were never emancipated, but rather freed themselves. ${ }^{195}$ The influence of Emancipation on identities of former slaves of Maroons and their descendents should be investigated as, after Emancipation, approximately half of the slaves of Maroons stayed in Maroon communities. The gender ratio of those who stayed was approximately equal. ${ }^{196}$ It is possible to conclude from this that economic opportunities throughout the rest of Jamaica were insufficient to encourage formerly enslaved people to leave the Maroon communities. Another possible interpretation of these data, however, is that enslaved people in

\footnotetext{
${ }^{192}$ David Barker and Balfour Spence, “Afro-Caribbean Agriculture: A Jamaican Maroon Community in Transition," The Geographical Journal 154 (1988): 199.

${ }^{193}$ Journals of the Assembly of Jamaica, 1773-1821

${ }^{194}$ Sally Price, "Sexism and the Construction of Reality: An Afro-American Example," American Ethnologist 10 (1983): 460.

${ }^{195}$ Harris Cawley, interview by author, Accompong, Jamaica, 7 August 2004.

${ }^{196}$ Votes of the Assembly of Jamaica, 1834-1837, quoted in Barbara Klamon Kopytoff, The Maroons of Jamaica: An Ethnohistorical Study of Incomplete Polities, 1655-1905 (Ph.D. diss., University of Pennsylvania, 1973), 178.
} 
Maroon communities, even prior to Emancipation, were well-enough integrated into the Maroon society that there was little impetus to leave.

However those enslaved to the Maroons regarded their situation, the Maroons likely regarded slavery as an integral aspect of Maroon freedom. However, to the Maroons, the power to define inclusion and exclusion from the polity was more than the luxury of identity politics; during the period when the Maroons struggled against the British, it was imperative to control membership in the rebel group for reasons of survival. Untrustworthy people lethally betrayed Maroons, and through the Asante blood oath and other means, the Maroons endeavored to ensure the security of their community. Other permutations of the oath ritual were, and are still, performed any time a non-Maroon witnesses an important Maroon ritual, such as the Kromanti Play. ${ }^{197}$ By delineating membership in the Maroon community in terms of allegiance to a sacred oath sworn to the gods, the Maroons have been able to create cohesive communities; the community cohesion is achieved by using ritual and mythic means to delineate clearly between community members and outsiders. Slavery, like the oath, appears to be one means by which Maroons ensured social cohesion. The power to define outgroups is a privilege of the free. While the Maroons lacked an ideology that reified slavery as ordained by nature or god, there is nothing in either the African or Jamaican experiences of the Maroons that would have made the institution of slavery appear to need justification.

Further examination of class and social structure of the Jamaican Maroons is clearly indicated. No record exists of modern Maroons tracing their heritage to former slaves of the Maroons, yet, given the Akan practice of assimilating slaves into the citizenry, and the fact that nearly half of the enslaved people did not leave Maroon communities after Emancipation, such people must exist. In conducting such an investigation, parallels with post-Emancipation Ghanaian society may emerge. However, the distinctiveness of Maroon culture and the unique imperative for virtually instantaneous construction of a viable and cohesive Maroon identity, render Maroon society, and the practice of slavery within it, discrete from both African antecedents and contemporaneous European constructions. Slavery on the Jamaican plantations clearly constituted slave society, and slavery in many African societies such as Asante also fit this mold; the segments of Igboland where slaves were not deployed in defensive villages are notable exceptions. It is difficult to draw conclusions based on these conjectural reconstructions of the role of slavery in the economy and society of the Jamaican Maroons. However, given the apparent role of slavery in the

${ }^{197}$ Bilby, "Swearing by the Past," 674-7. 
ethnogenesis of the Maroons, it appears that Jamaican Maroon society prior to emancipation was a society with slaves.

\section{MAROONS IN AFRICA: A COMPARISON}

The world the Jamaican Maroons and other New World Maroons created was, undoubtedly, a novel one, and maroonage is almost always discussed as a New World phenomenon. However, if there were slaves in the African societies from which those enslaved in the New World originated, and if the vast majority of those who violently rebelled or ran away were African, rather than creole, it is not unreasonable to believe that those who became the Maroons of Jamaica were acquainted with maroonage in Africa. Indeed, Genovese claims that the Atlantic trade in slaves included "some political rebels who had participated in revolts and maroon activity while still in Africa."198 Further, just as it is illuminating to compare slavery as practiced by different societies, it is also augments an understanding of the ethnogenesis of the Jamaican Maroons to examine the creation of maroon societies in Africa. Here, aspects of the Jamaican Maroon formation and society will be compared to the Tofinu, an ethnic group formed from refugees the slave raids and conquests of Dahomey in the late seventeenth and early eighteenth centuries, and to the communities that coalesced in the wake of the Mandingo Rebellion in modern-day Sierra Leone.

Genovese suggests a list of criteria that favored revolts and guerilla warfare against slavery in the New World; these criteria include the conditions that were present in regions with high incidences of revolt and maroonage in the New World, and whose absence in areas like the southern United States often characterized regions of relatively minimal revolt. Modified to inclusively apply to slavery both within and without the New World, these conditions are: 1) absenteeism and estrangement between masters and slaves; 2) famine and economic depravity; 3) large slaveholding units; 4) engagement of the slaveholding powers in frequent warfare against other polities; 5) large numerical majority of slaves over slaveholders; 6) greater presence of foreign-born slaves than creole slaves, or slaves born within the slaveholding society; 7) ability to form an autonomous leadership amongst the slaves; and 8) presence of geographical, social, and political conditions allowing for the formation of autonomous communities of runaways and rebels powerful enough to pose a threat to the slaveholders. ${ }^{199}$ Clearly, these qualities were all endemic to the slave society of Jamaica. When analyzing the resistance to the slave trade in Africa, some of these characteristics, such as

\footnotetext{
${ }^{198}$ Genovese, 19.

${ }^{199}$ Genovese, 11-2.
} 
absenteeism, size of slaveholdings, and the ability to form autonomous leadership, are not applicable. The final trait listed by Genovese, however, was crucial in both the New World and Africa, and those who successfully formed Maroon communities had to utilize every aspect of their environment as a weapon. Furthermore, social cohesion emerges from New World and African cases as crucial to the social, military, and political success of Maroon societies.

Perhaps the most well known example of a Maroon community in Africa is the lacustrine villages of the Tofinu in modern day Benin. The Tofinu, now a homogenous ethnic group, were originally refugees from various slaveholding societies in the area, and were most prominently of the Aja-Tado cultural group. ${ }^{200}$ Aja-speaking states included Sahe, Hogbonou, and Dahomey, which conquered Aja-speaking states Ouidah and Allada in the early seventeenth century. ${ }^{201}$ The language of the Tofinu, Tofingbe, is closely related to Aja. However, people of many other ethnic derivations contributed to the Tofinu, including, notably, the Yoruba, whose deity, Shango, is among the most widely worshipped by the Tofinu. ${ }^{202}$ Refugees from Nupe also joined the Tofinu in large numbers. $^{203}$

When Dahomey conquered Allada in 1724 and Ouidah in 1727, many people fled in terror, for Dahomey virtually controlled the trans-Atlantic slave commerce. When Dahomey sacked the cities of its rivals, thousands of people were enslaved and often sold. When Jakin was sacked in 1732, over four thousand people were enslaved; Dahomey was even more brutal in the capture of Savi, the capital of Ouidah. ${ }^{204}$ As the influence of Dahomey expanded, and as the slave trading efforts of the neighboring Porto Novo and Oyo polities intensified, more people fled to the region that would become Tofinuland, though refugees from the slave trade arrived in Tofinuland considerably earlier. ${ }^{205}$ Similarly, the increase in maroonage in Jamaica in the late seventeenth and early eighteenth centuries accompanied an intensification of production pressures on the Jamaican sugar plantations.

Tofinuland is an ideal environment for refugees. The land is part of a lagoon system on the lower So River, about forty kilometers from the coast, and includes Lake Nokoué. The Tofinu villages are located near lakes, are regularly flooded marshlands, or, most famously, are villages built

\footnotetext{
${ }^{200}$ Elisée Soumonni, "Lacustrine Villages in South Benin as Refuges from the Slave Trade," in Fighting the Slave Trade: West African Strategies, ed. Sylviane A. Diouf (Athens, OH: Ohio University Press, 2003), 7.

${ }^{201}$ July, 122.

${ }^{202}$ Soumonni, 7-10.

${ }^{203}$ A. Félix Iroko, Mosaiques d'Histoire Beninoise, vol. 1 (Tulle, France: Éditions Corrèze Buissonnière Peuple et Culture Corrèze, 1998), 75-6.

${ }^{204}$ Soumonni, 7.

${ }^{205}$ Iroko, 75.
} 
on stilts, entirely within lakes. ${ }^{206}$ Locating villages in such an environment, an extreme measure, protected the Tofinu from mounted attack; the soldiers of Dahomey were poor swimmers and not adept at navigation by canoe, as typified in the foundation story of the village Ganvié, where the Tofinu overturned a war canoe full of slave raiders. ${ }^{207}$ This ingenious use of the environment as a defense system by the Tofinu is reminiscent of the Jamaican Maroon use of the Cockpits and the Blue Mountains. For example, the Maroons utilized the unique topography of the Cockpits to trap pursuing soldiers in hidden sinkholes, from which they could not escape. ${ }^{208}$

As was the case for the Jamaican Maroons, the diversity of the Tofinu necessitated conscious social engineering to create an effective defense system. The Tofinu appeared to have engaged in deliberate and conscious mixing of the various elements of the society, including adopting the deities from most of constituent belief systems. There is some debate concerning the relative status of the various ethnicities who contributed to the Tofinu. Iroko argues that the Yoruba constituents were captured people whom the Aja-Tofinu initially intended to sell. ${ }^{209}$ Soummoni's oral sources in Ganvié indicated that while some of the refugees who came to Tofinuland had been previously enslaved, all who entered Tofinuland became free, and "nobody was permitted to come in and take them away for the purpose of selling or enslaving them." ${ }^{210}$ Though the evidence concerning the presence or absence of slaves to the Tofinu is inconclusive, it is clear that the "fear of permanent external aggression" and the rigors of the environment, in the case of the Tofinu as much as for the Jamaican Maroons, led to the creation of a new and cohesive ethnic identity within a brief period of time. $^{211}$

Thus, the formation of the Tofinu appears to coincide with many of the traits discussed by Genovese. The famine factor may be less important for those fleeing enslavement, though two serious droughts, including one of seven years' duration, struck the region in the seventeenth century, and a massive drought afflicted the entire Sahel region from 1740 until $1750 .{ }^{212}$ Dahomey's brutal conquest of rival states likely caused economic deprivation for those conquered, and it also

\footnotetext{
${ }^{206}$ Georges Bourgoignie, "Ethno-Ecologie d'une Collectivite Regionale: Les cities Lacustres du Dahomey" Canadian Journal of African Studies 6 (1972): 403-31.

${ }^{207}$ Soummoni, 8-9.

${ }^{208}$ Mark Wright, personal interview with the author, Accompong, Jamaica, 7 August 2004.

${ }^{209}$ Iroko, 75-6.

${ }^{210}$ Soummoni, 9-10.

${ }^{211}$ Soummoni, 10.

${ }^{212}$ Global Literacy Project, "Nigeria,” 2002. www.glpinc.org/Classroom\%20Activities/Nigeria\%20Articles/Nigeria\%27s\%20Early\%20History.htm, 17 April 2005.
} 
greatly increased the risk of being enslaved. Though the monarch of Dahomey had many personal slaves, it was more probably the large number of newly enslaved captives that made flight and open confrontation of Dahomey feasible. Dahomey was engaged in frequent conflict with neighboring states, and this conflict allowed the Tofinu to exist on the borderlands between Dahomey, Allada, Oyo, Nupe, and the Yoruba states. The resources required by these conflicts, and by persistent slave raiding, prevented Dahomey from being able to devote all of its resources to eradicating the Tofinu. Finally, the inimitable use of the lacustrine environment as a defensive strategy, in the absence of military equity with Dahomey, allowed the Tofinu to preserve their freedom, just as the Cockpits and Blue Mountains defended the Jamaican Maroons.

Such favorable environmental conditions were no less important to those who participated in the Mandingo Rebellion in 1785; in this instance, where the rebels were an enslaved resident population, many more of Genovese's criterion and similarities with the situation of the Jamaican Maroons existed. This rebellion was directed against the slaveholding elite of the state of Moriah, founded in the $1720 \mathrm{~s}$, and dominated by warriors, traders, and Islamic missionaries. ${ }^{213}$ In the expansion of the state between 1720 and 1760, Moriah encroached upon the territories of neighboring Bullom, Baga, and Temne, and captured many people from these states for sale in the trans-Atlantic trade and for use as domestic slaves. ${ }^{214}$ By the 1770 s, enslaved Bullom, Baga, and Temne comprised 70 to 80 percent of Moriah's population and produced the vast majority of rice, Moriah's major commodity. ${ }^{215}$ The economic centrality of the enslaved in Moriah and their numeric majority are analogous to the situation of the enslaved in Jamaica; furthermore, these enslaved people resided in slave villages, whose sole purpose was to create rice for the slaveholders, not unlike the sugar plantations is Jamaica. ${ }^{216}$

When, in 1785, Moriah went to war with neighboring Soso, "[t]he slaves took an opportunity, when the principal part of their fighting men were out on an expedition, to attack their masters, several of whom they put to death...they then set fire to the rice which was ready to be cut...[so] that their late masters were under necessity of suing for peace." ${ }^{217}$ Six to eight hundred people living in slave villages participated in this uprising, and then fled to Yangiakuri, Kani, and Funkoo, is Soso

\footnotetext{
${ }^{213}$ Ismail Rashid, "'A Devotion to the Idea of Liberty at Any Price': Rebellion and Antislavery in the Upper Guinea Coast in the Eighteenth and Nineteenth Centuries," in Fighting the Slave Trade: West African Strategies, ed.

Sylviane A. Diouf (Athens, OH: Ohio University Press, 2003), 139.

${ }^{214}$ Rashid, 140.

${ }^{215}$ David E. Skinner, Thomas George Lawson: African Historian and Administrator in Sierra Leone (Stanford, CA: Hoover Institution Press, 1980), 52-8.

216 Rashid, 140.

${ }^{217}$ John Matthews, A Voyage to the River Sierra- Leone (London: Cass, 1788), 154-5.
} 
country, and in the foothills of mountains. In Yangiakuri, the refugees built twelve-foot mud walls and security towers. ${ }^{218}$ This choice of refuge recalls the Jamaican Maroon defensive systems in the Cockpits and in the Blue Mountains, where stone structures built by the British when they briefly occupied the site in the 1730 s were later used by the Maroons defending the site. ${ }^{219}$ As did the Jamaican Maroons, the Mandingo rebels also encouraged other enslaved peoples to join them. ${ }^{220}$

The Mandingo rebels were initially tolerated or supported by Soso, but when Soso and Moriah made peace in 1795, Moriah and Soso allied against the rebels, who, increasingly, included refugees from the enslaved people of Soso. The smaller settlements were quickly conquered, and the inhabitants were killed or sold into slavery. Yangiakuri proved more difficult to defeat. After besieging the town and setting fire to the houses with flaming arrows, the combined armies killed about four hundred of the village's nine hundred residents. The rebels inflicted high casualties on the Moriah-Soso army, reducing it by more than half, according to one estimate. When one of the rebel leaders was betrayed and killed as he tried to acquire more military supplies, Yangiakuri was defeated, and "the majority of the residents... were killed or sold into slavery...[a] small number...escaped and were able to found a settlement in Bena, a Soso polity on the upper reaches of the Great Scarcies River."221 The ardent defense of the communities certainly is similar to that of the Jamaican Maroons. No information is available on the degree to which the diverse ethnicities enslaved in Moriah coalesced into a unified identity during this period of rebellion; however, the fact that the Mandingo rebels encouraged others to join them, and that all fought to defend Yangiakuri, suggests a relatively high degree of unity amongst the disparate participants in the Mandingo Rebellion.

The situation of the Mandingo Rebellion appears to meet virtually all of Genovese's criteria for a rebellion-prone slave society. The enslaved people who rebelled lived in slave villages from which the masters were almost always absent. There does not appear to have been a famine during the late eighteenth century in Sierra Leone, nor any particular economic depravation. The rice plantations were populated by large numbers of enslaved people, as evinced by the quantity of people who participated in the Rebellion. The Mandingo Rebellion could not have initially succeeded without the brilliant planning on the part of its leaders, who waited until most of Moriah's military was engaged with Soso; while Moriah remained at war, the rebels remained free, and they

\footnotetext{
${ }^{218}$ Rashid, 140-1.

${ }^{219}$ Agorsah, “Archaeology of Maroon Settlements in Jamaica,” 182.

${ }^{220}$ Rashid, 141.

${ }^{221}$ Rashid, 141-2.
} 
were not defeated until Moriah and Soso allied. The enslaved greatly outnumbered the free in Moriah, and newly captured people were sent to the rice plantations. ${ }^{222}$ The rebels clearly developed their own leadership, which not only planned the enormously successful initial rebellion, but also organized the rebel polities effectively. That Yangiakuri was only defeated when its leader was captured is an eloquent testimony to the efficacy of its leadership. Lastly, the Mandingo rebels used mountains and rivers to their great advantage, much as they used the contention between Moriah and Soso.

Though the Mandingo Rebellion occurred significantly after the Jamaican Maroons successfully gained their autonomy, it is but one vivid example of a general trend of maroonage and flight which characterized African responses to slavery and the slave trade throughout Africa. It is even possible that some Maroons knew of the Tofinu, or of other rebel and refugee groups. The conditions that produced these communities are similar to those that gave rise to the Jamaican Maroons, and the strategies that were successful in these situations are remarkably alike. Genovese's model is but one way of describing the commonalities between these situations, but it helps to demonstrate that the responses of enslaved people to slavery, both in Africa and in the New World, whether arising completely independently or through some mechanism of transmission, share a great many features. It thus seems that comparative maroonage is an important field of study that should be investigated in earnest.

\section{CONCLUSION}

The Jamaican Maroons are thus both unique and part of a continuity of culture and maroonage. In the specific ways in which the Maroons fought against the British, secured their autonomy, and rapidly created a new and cohesive ethnicity, their original innovations are clear. However, the means by which the disparate rebels and refugees became Maroons are clearly adapted from African practices. The new mythology of the Maroons borrowed from recognizable mythic structures of Africa, and the kinship metaphor which extended from this mythology is distinctly African in nature. Even maroonage, so often regarded as unique to the plantation slavery societies in the New World, has African antecedents and analogs. The Maroons created their society in response to the particular needs of their social, physical, political, and spiritual environment, but they modified patterns of behavior and belief from Africa to do this. Thus, the seeming contradiction

\footnotetext{
${ }^{222}$ Rashid, 140.
} 
between novelty and continuity can be resolved by understanding Maroons adaptations as a process of synthesis and adjustment.

Any study of the Jamaican Maroons must confront a profusion of apparent contradictions. Most often emphasized is the seeming paradox of rebel slave communities that turned against rebel and refugee slaves. As has been shown, the Maroons conceived of themselves as an independent ethnicity, and, no matter how much enslaved people, Paul Bogle, or twentieth-century and twentyfirst-century people may have wished, or continue to desire, for it to be otherwise, the Maroons were not freedom fighters. The shame that accompanies an examination of slavery, both for the descendents of the enslaved and for the descendents of the slaveholders, cannot be dissipated or diffused by placing the burden for overthrowing a system of racialized slavery upon the Maroons. This was not their goal, nor was it a struggle which they recognized. The weight of shame cannot be projected onto eighteenth-century Maroons; rather, it must be confronted in the systems of inequity which continue to be perpetuated today.

For inequities do persist, even after independence. Maroons continue to lack basic services in their communities, such as running water and functional roads. Economic opportunities for young Maroons who wish to stay within their communities are limited, and the crime, chronically high unemployment and poor housing conditions those who leave must face is not encouraging. Despite the prevalence of Pan-Africanist ideology in modern Jamaica, there is a noted lack of umoja, ujima, and ujama in the society at large. These principals, however, were fundamental to the creation of the Maroon polities, and persist to day in such ways as collective Maroon ownership of Maroon lands. Eighteenth-century Maroons were not revolutionaries, but they did understand the importance of collective action, collective belief, and unity. 
Works Cited

Agorsah, E. Kofi. “Archaeology of Maroon Settlements in Jamaica.” In Maroon Heritage, edited by E. Kofi Agorsah. Kingston, Jamaica: Canoe Press, 1994.

Agorsah, E. Kofi, editor. Maroon Heritage. Kingston, Jamaica: Canoe Press, 1994.

An Essay Concerning Slavery and the Danger Jamaica is Expos'd to From Too Great

Number of Slaves... London, 1746.

Barker, David and Balfour Spence. "Afro-Caribbean Agriculture: A Jamaican Maroon Community in Transition.” The Geographical Journal 154 (1988): 198-208

Beckles, Hilary. Review of The Maroons of Jamaica, 1655-1796: A History of Resistance, Collaboration and Betrayal, by Mavis C. Campbell. The Journal of American History 76 (1989): 579.

Berlin, Ira. Generations of Captivity: A History of African-American Slaves. Cambridge, MA: Harvard University Press, 2003.

Berlin, Isaiah. Four Essays on Liberty. New York: Oxford University Press, 1969.

Bilby, Kenneth. "Swearing by the Past, Swearing to the Future: Sacred Oaths, Alliances, and Treaties among the Guianese and Jamaican Maroons.” Ethnobistory 44 (Fall 1997): 655-689.

Bilby, Kenneth. "Two Sister Pikni': A Historical Tradition of Dual Ethnogenesis in Eastern Jamaica.” Caribbean Quarterly 30 (1984): 10-25.

Bourgoignie, Georges. 'Ethno-Ecologie d'une Collectivite Regionale: Les cities Lacustres du Dahomey." Canadian Journal of African Studies 6 (1972): 403-31.

Brathwaite, Kamau. "Nanny, Palmares and the Caribbean Maroon Connexion” in 
Maroon Heritage. Edited by E. Kofi Agorsah. Jamaica: Canoe Press, 1994.

British CO 137/19.

British C.O. 137/21, Board of Trade to Newcastle, October 7, 1730.

British C.O. 137/23. Trelawny to Board of Trade, March 30, 1739.

British C.O. 137/56. Trelawny to Guthrie, February 23, 1738.

British C.O. 137/56. Trelawny to Newcastle, July 7, 1737.

British C.O. 137/56, June 30, 1739.

Broadhead, Susan Herlin. "Slave Wives, Free Sisters: Bakongo Women and Slavery c. 1700-1850." In Women and Slavery in Africa, edited by Claire C. Robertson and Martin A. Klein. Madison, WI: The University of Wisconsin Press, 1983.

Burnard, Trevor and Kenneth Morgan. "The Dynamics of the Slave Market and Slave Purchasing in Jamaica, 1655-1788.” William and Mary Quarterly 58 (2001): 205-7.

Burnard, Trevor. Mastery, Tyranny, and Desire: Thomas Thistlewood and His Slaves in the Anglo-Jamaican World. Chapel Hill: The University of North Carolina Press, 2004.

Campbell, Gwyn. "Madagascar and the Slave Trade, 1810-1895." The Journal of African History 22 (1981): 203-227.

Campbell, Mavis C. The Maroons of Jamaica 1655-1796: A History of Resistance, Collaboration, and Betrayal. Massachusetts: Bergin \& Garvey Publishers, Inc, 1988.

Cawley, Harris. Interview by author. Accompong, Jamaica. 7 August 2004.

Claims for Compensation Filed With the Assistant Commissioners for Jamaica. National 
Library of Jamaica. Kingston, Jamaica.

Codrington to Council of Trade and Plantations. 30 December 1701. Quoted in Mavis

Campbell, The Maroons of Jamaica, 1655-1796: A History of Resistance,

Collaboration and Betrayal (Massachusetts: Bergin and Garvey Publishers, 1988), 45.

Curtin, Philip. The Atlantic Slave Trade: A Census. Madison, WI: University of Wisconsin Press, 1969.

Dallas, Robert Charles. The History of the Maroons: From Their Origin to the Establishment of Their Chief Tribe at Sierra Leone. Volume 1. London: Frank Cass and Company, 1803; reprint, 1968.

Eltis, David, Stephen D. Behrendt, David Richardson, and Herbert S. Klein, editors. The Trans-Atlantic Slave Trade: A Database on CD-ROM. Cambridge, UK: Cambridge University Press, 1999.

Genovese, Eugene D. From Rebellion to Revolution: Afro-American Slave Revolts in the Making of the Modern World. Baton Rouge, LA: Louisiana State University Press, 1981.

Global Literacy Project, "Nigeria." 2002. www.glpinc.org/Classroom $\% 20$ Activities /Nigeria $\% 20$ Articles $/$ Nigeria $\% 27 \mathrm{~s} \% 20 \mathrm{Early} \% 20 \mathrm{H}$ istory.htm. 17 April 2005.

Gottlieb, Karla L. "The Mother of Us All" A History of Queen Nanny, Leader of the Windward Jamaican Maroons. Trenton, NJ: Africa World Press, Inc., 2000.

Graves, Robert and Raphael Patai. Hebrew Myths: The Book of Genesis. Garden City, NY: Doubleday, 1964.

Handler, Jerome S. and John T. Pohlmann. "Slave Manumissions and Freedmen in 
Seventeenth-Century Barbados." The William and Mary Quarterly 41 (1984): 390-408.

Harris, C.L.G. “The True Traditions of My Ancestors.” In Maroon Heritage, edited by E. Kofi Agorsah. Kingston, Jamacia: Canoe Press, 1994.

Henige, David P. “The Problem of Feedback in Oral Tradition: Four Examples From the Fante Coastland." The Journal of African History 14 (1973): 223-235.

Hopkins, Anthony G. An Economic History of West Africa. New York: Columbia University Press, 1973.

Horsman, Reginald. “Origins of Racial Anglo-Saxonism in Great Britain Before 1850." Journal of the History of Ideas, Vol. 37, No. 3 (July-Sept. 1976): 387-410.

Iroko, A. Félix. Mosaiques d'Histoire Beninoise. Volume 1. Tulle, France: Éditions Corrèze Buissonnière Peuple et Culture Corrèze, 1998.

Jacquemin, Nicolas. "Journal de Mon Voyage Chez les Indiens et les Negres Refugies sur Nos Terres, Fait en Decembre 1782." Reproduced in Jean Hurault. "Histoire des Noirs Réfugies Boni de la Guyane Française (d’Après les Documents des Sources Françaises)." Revue Française d'Histoire d'Outre-Mer 47 (1960): 98-101, translated in Bilby, "Swearing by the Past, Swearing to the Future: Sacred Oaths, Alliances, and Treaties among the Guianese and Jamaican Maroons." Ethnohistory 44 (Fall 1997): 655-689.

Jamaican Ministry of Youth, Education, and Culture. Jamaica's National Heroes. 2001.

< http://www.moec.gov.jm/heroes/nannycont.htm> (11 May 2004).

Journals of the Assembly of Jamaica.

July, Robert W. A History of the African People. $5^{\text {th }}$ ed. Prospect Heights, IL:

Waveland Press, 1998. 
Klein, A. Norman. 'The Two Asantes: Competing Interpretations of 'Slavery' in AkanAsante Culture and Society." in The Ideology of Slavery in Africa, edited by Paul E. Lovejoy. Beverly Hills, CA: Sage Publications, 1981.

Kopytoff, Barbara Klamon. "Colonial Treaty as Sacred Charter of the Jamaican Maroons." Ethnohistory 26 (1979): 45-64.

Kopytoff, Barbara Klamon. “The Development of Jamaican Maroon Ethnicity.” Caribbean Quarterly 22 (1976): 33-50.

Kopytoff, Barbara Klamon. The Maroons of Jamaica: An Ethnohistorical Study of Incomplete Polities, 1655-1905. Ph.D. diss., University of Pennsylvania, 1973.

Kopytoff, Igor and Suzanne Miers. "African 'Slavery' as an Institution of Marginality." in Slavery in Africa: Historical and Anthropological Perspectives, editors Igor Kopytoff and Suzanne Miers. Madison, WI: The University of Wisconsin Press, 1977.

Land Patent to Nanny, 1740. British Patents Volume 22, Folio $15 \mathrm{~B}$.

Long, Edward. History of Jamaica. 3 volumes. 1774; reprint, London: Frank Cass, 1970.

Maier, Pauline. American Scripture: Making the Declaration of Independence. New York: Random House, 1998.

Mamdani, Mahmood. When Victims Become Killers: Colonialism, Nativism, and the Genocide in Rwanda. Princeton: Princeton University Press, 2001.

Matthews, John. A Voyage to the River Sierra- Leone. London: Cass, 1788.

McCaskie, T.C. State and Society in Pre-Colonial Asante. Cambridge, UK: Cambridge University Press, 1995. 
Meillassoux, Claude. The Anthropology of Slavery: The Womb of Iron and Gold.

Translated by Alide Dasnois. London: The University of Chicago Press, 1991.

Niane, Djibril Tamsir. “Africa’s Understanding of the Slave Trade: Oral Accounts." Diogenes 45 (1997): 75-90.

Nussbaum, Felicity A. The Limits of the Human: Fictions of Anomaly, Race, and Gender in the Long Eighteenth Century. New York: Cambridge University Press, 2003.

Oldfield, J.R. "The London Committee and Mobilization of Public Opinion Against the Slave Trade." The Historical Journal 35 (1992): 331-343.

Oxford English Dictionary, 2 $2^{\text {nd }}$ ed., s.v. "Chattel."

Oxford English Dictionary, $2^{\text {nd }}$ ed., s.v. "Maroon."

Patterson, Orlando. The Sociology of Slavery: An Analysis of the Origins, Development and Structure of Negro Slave Society in Jamaica. Rutherford, N.J.: Fairleigh Dickinson University Press, 1969.

Peddie, Sydney. Interview by author. Accompong, Jamaica. 7 August 2004.

Pinkerton, John. A Dissertation on the Origin and Progress of the Scythians or Goths Being an Introduction to the Ancient and Modern History of Europe. London, 1787.

Price, Richard. First Time: The Historical Vision of an Afro-American People. Baltimore: The Johns Hopkins University Press, 1983.

Price, Sally. "Sexism and the Construction of Reality: An Afro-American Example." American Ethnologist 10 (1983): 
Rashid, Ismail. "'A Devotion to the Idea of Liberty at Any Price': Rebellion and

Antislavery in the Upper Guinea Coast in the Eighteenth and Nineteenth Centuries." In Fighting the Slave Trade: West African Strategies, edited by Sylviane A. Diouf. Athens, OH: Ohio University Press, 2003.

Raynal, Guillaume. A Philosophical and Political History of the Settlements and Trade of the Europeans in the East and West Indies. 5 volumes. Translated by J. Justamond. Dublin, 1779.

Reid, Victor. Interview by author. Accompong, Jamaica. 6 August 2004.

Renny, Richard. A History of Jamaica. London, 1807.

Robertson, Claire C. and Martin A. Klein. 'Women's Importance in African Slave Systems." in Women and Slavery in Africa, edited by Claire C. Robertson and Martin A. Klein. Madison, WI: The University of Wisconsin Press, 1983.

Robinson, Carey. "Maroons and Rebels (A Dilemma)." In Maroon Heritage, edited by E. Kofi Agorsah. Kingston, Jamaica: Canoe Press, 1994.

Rous, Laura Samsom and Hans Samsom. Tree of Forgetfulness. Amsterdam: Koninklijk Instituut Voor de Tropen, 2004.

Ryder, A.F.C. Benin and the Europeans. New York: Humanities Press, 1969.

Sanders, Edith R. "The Hamitic Hypothesis: Its Origin and Functions in Time Perspective," Journal of African History, 10 (1969): 521-532.

Schaefer, Daniel Lee. “The Maroons of Jamaica.” Ph.D. diss., University of Minnesota, 1973. 
Rashid, Ismail. "'A Devotion to the Idea of Liberty at Any Price': Rebellion and

Antislavery in the Upper Guinea Coast in the Eighteenth and Nineteenth Centuries." In Fighting the Slave Trade: West African Strategies, edited by Sylviane A. Diouf. Athens, OH: Ohio University Press, 2003.

Raynal, Guillaume. A Philosophical and Political History of the Settlements and Trade of the Europeans in the East and West Indies. 5 volumes. Translated by J. Justamond. Dublin, 1779.

Reid, Victor. Interview by author. Accompong, Jamaica. 6 August 2004.

Renny, Richard. A History of Jamaica. London, 1807.

Robertson, Claire C. and Martin A. Klein. 'Women's Importance in African Slave Systems." in Women and Slavery in Africa, edited by Claire C. Robertson and Martin A. Klein. Madison, WI: The University of Wisconsin Press, 1983.

Robinson, Carey. "Maroons and Rebels (A Dilemma)." In Maroon Heritage, edited by E. Kofi Agorsah. Kingston, Jamaica: Canoe Press, 1994.

Rous, Laura Samsom and Hans Samsom. Tree of Forgetfulness. Amsterdam: Koninklijk Instituut Voor de Tropen, 2004.

Ryder, A.F.C. Benin and the Europeans. New York: Humanities Press, 1969.

Sanders, Edith R. "The Hamitic Hypothesis: Its Origin and Functions in Time Perspective," Journal of African History, 10 (1969): 521-532.

Schaefer, Daniel Lee. “The Maroons of Jamaica.” Ph.D. diss., University of Minnesota, 1973. 